Discussion Paper No. 09-001

\title{
Interactions of Reduced Deforestation
} and the Carbon Market: The Role of Market Regulations and Future Commitments

Niels Anger, Alistair Dixon, and Erich Livengood

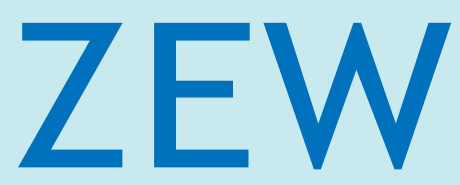

Zentrum für Europäische Wirtschaftsforschung $\mathrm{GmbH}$

Centre for European

Economic Research 
Discussion Paper No. 09-001

\section{Interactions of Reduced Deforestation and the Carbon Market: The Role of Market Regulations and Future Commitments}

Niels Anger, Alistair Dixon, and Erich Livengood

Download this ZEW Discussion Paper from our ftp server:

ftp://ftp.zew.de/pub/zew-docs/dp/dp09001.pdf

Die Discussion Papers dienen einer möglichst schnellen Verbreitung von neueren Forschungsarbeiten des ZEW. Die Beiträge liegen in alleiniger Verantwortung der Autoren und stellen nicht notwendigerweise die Meinung des ZEW dar.

Discussion Papers are intended to make results of ZEW research promptly available to other economists in order to encourage discussion and suggestions for revisions. The authors are solely responsible for the contents which do not necessarily represent the opinion of the ZEW. 


\section{Non-Technical Summary}

With emissions from land use change representing up to 20 percent of anthropogenic greenhouse gas emissions, reducing emissions from deforestation and degradation (REDD) has been proposed as a potentially inexpensive and plentiful source of emission abatement. However, critics doubt that REDD credits are environmentally equivalent to domestic emission reductions, and suggest an excess supply may disrupt carbon markets. In this context, this paper investigates the economic implications of alternative emissions market regulations and future emissions reduction commitments, as well as uncertainties in REDD credit supply. Numerical simulations with a multi-country equilibrium model of the global emissions market show that unrestricted exchange of REDD units reduces the international carbon price by half and cuts Annex I compliance costs by roughly one third. Restricting the supply or demand of REDD credits limits price impacts, but comes at the cost of economic efficiency. Alternatively, Annex I reduction commitments could be increased by almost two thirds at constant carbon prices. Regarding uncertainties around the cost and scope of REDD credit supply, we find that both international permit prices and Annex I compliance costs are fairly robust to alternative supply functions.

\section{Das Wichtigste in Kürze}

Da Emissionen aus Landnutzung und tropischer Entwaldung bis zu einem Fünftel der anthropogenen Treibhausgasemissionen ausmachen, wird in der aktuellen klimapolitischen Debatte die Verringerung von Kohlenstoffemissionen aus Abholzungsaktivitäten als bedeutende und kostengünstige Maßnahme des Klimaschutzes vorgeschlagen. Kritiker bezweifeln jedoch, dass die Emissionseinsparungen durch vermiedene Entwaldung ökologisch äquivalent zu Emissionsvermeidungen in Industrieländern sind und befürchten ein Überschussangebot von Emissionszertifikaten. Vor diesem Hintergrund untersucht die vorliegende Studie die ökonomischen Implikationen von Regulierungen des Emissionsmarktes sowie Unsicherheiten über das Angebot an Zertifikaten aus vermiedener Entwaldung. Numerische Simulationen mit einem Gleichgewichtsmodell des globalen Emissionsmarktes zeigen, dass ein unbeschränkter Emissionshandel den internationalen Zertifikatpreis um bis zu 50 Prozent reduzieren würde. Die Beschränkung des Angebots von bzw. der Nachfrage nach Zertifikaten limitiert zwar solche Preiseffekte, begrenzt jedoch gleichzeitig die ökonomische Effizienz der Klimapolitik. Als Alternative könnten Industrieländer ihre Klimaschutzziele mit Hilfe vermiedener Entwaldung um fast zwei Drittel erhöhen, ohne den internationalen Zertifikatpreis zu beeinflussen. 


\title{
Interactions of Reduced Deforestation and the Carbon Market:
}

\section{The Role of Market Regulations and Future Commitments}

\author{
Niels Anger ${ }^{1, *}$, Alistair Dixon ${ }^{2}$ and Erich Livengood ${ }^{2}$
}

\begin{abstract}
Reducing emissions from deforestation and degradation (REDD) has been proposed as a potentially inexpensive and plentiful source of emission abatement to supplement other longterm climate policies. However, critics doubt that REDD credits are environmentally equivalent to domestic emission reductions, and suggest an excess supply may disrupt carbon markets. In this context, we investigate the economic implications of emissions market regulations and future emissions reduction commitments, as well as uncertainties in REDD credit supply. Numerical simulations with a multi-country equilibrium model of the global emissions market show unrestricted exchange of REDD units reduces the international carbon price by half and cuts Annex I compliance costs by roughly one third. Restricting supply or demand of REDD credits reduces price impacts, but comes at the cost of economic efficiency. Alternatively, Annex I reduction commitments could be increased by almost two thirds at constant carbon prices. While REDD provides large economic benefits for tropical rainforest regions, any REDD policy scenario also reduces wealth transfers to traditional CDM host countries through increased competition on the supply-side of the carbon market.
\end{abstract}

JEL classification: C60, D61, Q23, Q58

Keywords: Climate Change, Kyoto Protocol, Emissions Trading, Deforestation, REDD

Acknowledgements: The authors would like to thank Rachel Holden for helpful research support and Andreas Löschel for valuable scientific advice. Funding by the New Zealand Ministry of Agriculture and Forestry is gratefully acknowledged.

\footnotetext{
${ }^{1}$ Centre for European Economic Research (ZEW), Mannheim, Germany

${ }^{2}$ The Marketplace Company Limited (M-Co), Wellington, New Zealand. E-mails: alistair.dixon@m-co.co.nz, erich.livengood@m-co.co.nz
}

* Corresponding author. Address: Centre for European Economic Research (ZEW), P.O. Box 103443,68034 Mannheim, Germany. E-mail: anger@zew.de, niels.anger@gmail.com 


\section{Introduction}

With emissions from land use change representing up to 20 percent of anthropogenic greenhouse gas emissions, reducing emissions from deforestation and degradation (REDD) has been proposed as a potentially inexpensive and plentiful source of emission abatement. Proposals for including REDD in the global response to climate change have gained momentum in recent years. While the basic premise of REDD is universal to all proposals - that emissions are avoided through reductions in the rate of deforestation-virtually all other aspects, from measurement methodologies to financing sources, are still being debated in the lead up to the 2009 UN Climate Change Conference in Copenhagen.

A number of REDD proposals identify global funds or emissions trading markets, or both, as preferred sources of funding. Advocates of market-based approaches refer to the benefits of allocative efficiency and the ability to mobilise the large amounts of capital required to enable the potential large emissions reductions. In this context, the Eliasch Review emphasized the importance of including the forest sector in international emissions trading schemes, as this would substantially reduce the costs of reducing global carbon emissions and lower costs would enable more ambitious overall emissions targets (Eliasch, 2008). However, for a REDD market mechanism to advance, two key prerequisites will need to be addressed: that REDD credits are environmentally equivalent to other compliance units and that REDD units will not "flood" emissions markets with excess supply. Regarding the first issue, in particular the adequate estimation of reduced emissions remains a challenge and linking distribution of carbon finance to countries' efforts of slowing deforestation rates has been proposed (Combes Motel et al., 2009). Regarding the second prerequisite, the European Commission notes that the introduction of REDD units into the EU ETS could result in a serious supply and demand imbalance (European Commission, 2008). The associated diminishing of carbon price signals could restrain technological change towards a low-carbon economy. Also the scope and costs of REDD credit supply itself are thus far uncertain: questions about the exact baseline rate of deforestation, regional differences in carbon sequestration potential, as well as the opportunity costs of REDD (in terms of foregone land use returns and forest product prices) remain unanswered.

We focus on the carbon market implications of REDD by studying the role of carbon market regulations and future emissions reduction commitments, as well as uncertainties in REDD credit 
supply. Restricting the supply and demand of REDD credits has been proposed to limit a flooding of the post-2012 carbon market. Alternatively, an increase in commitments of industrialized countries would increase credit demand and thus limit price impacts. Uncertainties in the scope and costs of REDD credit supply might substantially alter the associated carbon market effects.

The economic aspects of international emissions trading have been assessed in a number of previous quantitative studies of the Kyoto Protocol and the EU ETS (e.g. Weyant and Hill, 1999; Böhringer et al., 2005; Klepper and Peterson, 2006). The quantitative economic literature assessing deforestation in the context of climate policy is comparably scant. Linking a forestry model to a climate-economy model, Sohngen and Mendelsohn (2003) analyze the general role of forests in greenhouse gas mitigation, predicting forest sequestration to account for about one third of global carbon abatement within the next century. Tavoni et al. (2007) study the contribution of forestry management to long-term $\mathrm{CO}_{2}$ stabilization policies, finding that increased forest sequestration could significantly lower the global costs of climate policy. Studies focusing on the emissions-market implications of REDD include Anger and Sathaye (2008), who provide a first assessment of the economic implications of crediting REDD for the post-Kyoto carbon market. Cabezas and Keohane (2008) find that forest carbon credits from developing countries, including REDD credits, have considerable potential to help limit the costs of compliance with cap-andtrade systems in the EU and the United States. While the principle economic interactions between REDD and carbon markets have been assessed before, these previous studies abstract from three important issues: the role of policies which restrict REDD credit demand or supply, the potential for expanded commitments through REDD and REDD cost and supply uncertainties.

Against this background, we study the carbon-market implications of integrating REDD in the year 2020. In order to assess the role of market regulations, future commitments and uncertainties in REDD supply we employ a multi-country numerical equilibrium model of the global carbon market which incorporates marginal cost functions for carbon abatement from reduced deforestation. The model covers international emissions trading at the government level as facilitated by a post-Kyoto agreement and enables an explicit assessment of international carbon permit trade flows generated from the introduction of REDD.

The remainder of this paper is organized as follows. Section 2 presents our numerical model framework. Section 3 provides a brief economic background on carbon market regulations. The quantitative simulation results are presented in Section 4. Section 5 concludes. 


\section{Numerical framework}

\subsection{Model framework}

In order to quantify the carbon market impacts of reducing deforestation we employ a numerical equilibrium model of the global carbon market, which incorporates marginal abatement cost functions for reduced deforestation.

\section{Accounting for the forestry sector in tropical regions}

In order to represent the response of the forestry sector to changes in future carbon prices, we incorporate data from the dynamic partial equilibrium model Generalized Comprehensive Mitigation Assessment Process GCOMAP (Sathaye et al., 2005, 2006). This model explicitly analyzes the carbon benefits of forestation globally in ten regions and of reducing deforestation in four important tropical rainforest regions (FAO, 2007): Africa, South-East Asia, Central America and South America. It establishes a reference case level of land use, absent carbon prices, for 2000 to 2100 before simulating the response of forest land users to changes in prices in forest land and products, as well as prices emerging in carbon markets. The model's objective is to estimate the land area that land users would plant above the reference case level, or prevent from being deforested, in response to carbon prices. As a result GCOMAP estimates the net changes in carbon stocks while meeting the annual demand for timber and non-timber products. In order to consider the role of institutional barriers for crediting carbon abatement from reducing deforestation GCOMAP accounts for transaction costs of forestry projects and programs (hereafter also referred to as projects, see Antinori and Sathaye, 2007). Such transaction costs may arise from project search, feasibility studies, as well as negotiation, monitoring and verification, regulatory approval, and insurance costs.

Proposals for the inclusion of REDD credits in international carbon markets have included provisions for project-based crediting and for national-level crediting. Under national-level crediting, individual nations are compensated for performance in reducing deforestation. In order to achieve reduced national deforestation, nations aggregate projects at the domestic level and implement relevant policies and measures. While GCOMAP explicitly models projects, we 
generalise the resultant regional marginal abatement cost functions to represent regional aggregations of national-level crediting cost functions. ${ }^{1}$

\section{Modelling the global carbon market including reduced deforestation}

In order to quantitatively assess the emissions market impacts of reducing deforestation we employ a numerical multi-country, two-sector partial equilibrium model of the global carbon market in 2020. For each region, the model incorporates calibrated marginal abatement cost functions for energy-intensive and non-energy-intensive sectors. Building on the modelling framework of Anger (2007), the core model represents parallel carbon markets for (i) companies covered by the EU ETS and emerging schemes outside Europe as well as (ii) post-Kyoto governments in 2020 and accounts for emissions reductions via the CDM. For this study, we focus on the carbon market for post-Kyoto governmental compliance. The objective of the model is to minimize compliance costs of achieving targeted carbon emissions reductions by means of international emissions trading. An algebraic model summary is given in Anger (2008).

To generate marginal abatement cost (MAC) functions by region and sector we use data simulated by the well-known energy-system model POLES (Criqui et al., 1999), which explicitly covers energy technology options for emissions abatement in various world regions and sectors for the base year 2020. In the POLES simulations a sequence of carbon taxes (e.g. 0 to 100 US\$ per ton of carbon) is imposed on the respective regions, resulting in associated sectoral emissions abatement. The coefficients for MAC functions in 2020 are estimated by an ordinary least squares (OLS) regression of tax levels (i.e. marginal abatement costs) on associated emissions abatement. Following Böhringer et al. (2005), in order to assure for functional flexibility, a polynomial of third degree is chosen as the functional form of MAC functions. ${ }^{2}$ For region $r$ and sector $i$ this results in the following equation (here, EIS and NEIS denote energy-intensive and non-energy-intensive sectors, respectively):

$$
-\operatorname{MAC}_{i r}\left(e_{i r}\right)=\beta_{1, i r}\left(e_{0 i r}-e_{i r}\right)+\beta_{2, i r}\left(e_{0 i r}-e_{i r}\right)^{2}+\beta_{3, i r}\left(e_{0 i r}-e_{i r}\right)^{3}
$$

\footnotetext{
${ }^{1}$ In this paper, it is assumed that the REDD-derived units (as delivered to the market) are environmentally equivalent to other trading units. This assumption allows us to discuss exclusively the carbon market impacts of REDD integration.

${ }^{2}$ We use the OLS approach as a standard estimation technique, which for our data yields parameter estimations with a high overall goodness-of-fit. Clearly alternative estimation approaches and functional forms could be chosen here.
} 
with $M A C_{i r}$ as marginal abatement cost in region $r$ and sector $i \in\{E I S, N E I S\}, \beta_{1, i r}, \beta_{2, i r}$ and $\beta_{3, i r}$ as marginal abatement cost coefficients, $e_{0 i r}$ as baseline emissions level in 2020 and $e_{i r}$ as emissions level after abatement. Table 3 in Appendix A shows the resulting least-square estimates of MAC coefficients by region and sector in $2020 .^{3}$

Following Anger and Sathaye (2008), MAC functions for reducing deforestation are generated by imposing a sequence of carbon prices (here: 0 to 100 US\$ per ton of carbon) in four tropical rainforest regions with the GCOMAP model: Africa, South-East Asia, Central America and South America. This results in a sequence of regional net carbon stock changes and the corresponding carbon emissions reductions due to avoided deforestation. Based on these pricequantity pairs we are able to estimate the coefficients of regional MAC functions in 2020 by means of an OLS regression. Finally, these MAC coefficients are implemented into the carbon market model by covering tropical rainforest areas as explicit model regions. Within this linked model framework, tropical rainforest regions may export emissions reduction credits from reducing deforestation to industrialised model regions via the global carbon market. Table 4 in Appendix A presents the estimated marginal abatement cost coefficients for avoided deforestation for the four tropical regions in 2020.

Table 1 presents the regional groupings of the carbon-market model as well as the classification of regions into Annex I regions, CDM host countries and tropical rainforest regions. ${ }^{4}$

Table 1 Regional participation in 2020

\begin{tabular}{|c|c|c|}
\hline $\begin{array}{c}\text { International emissions } \\
\text { trading (Annex I) regions }\end{array}$ & CDM regions & $\begin{array}{c}\text { Tropical rainforest } \\
\text { regions }\end{array}$ \\
\hline EU-27 & Brazil & Africa \\
Canada & China & South-East Asia \\
Japan & India & Central America \\
Former Soviet Union & Mexico & South America \\
Pacific OECD & South Korea & \\
United States & & \\
\hline
\end{tabular}

\footnotetext{
${ }^{3}$ The marginal abatement cost coefficients have the following units:

$\beta_{1, i r}\left[\left(€ 2005 / \mathrm{tCO}_{2}\right) / \mathrm{MtCO}_{2}\right], \beta_{2, \text { ir }}\left[\left(€ 2005 / \mathrm{tCO}_{2}\right) /\left(\mathrm{MtCO}_{2}\right)^{2}\right]$ and $\beta_{3, i r}\left[\left(€ 2005 / \mathrm{tCO}_{2}\right) /\left(\mathrm{MtCO}_{2}\right)^{3}\right]$.

${ }^{4}$ The Pacific OECD region essentially comprises Australia and New Zealand.
} 


\subsection{Baseline emissions and reduction targets}

Baseline or business-as-usual (BAU) carbon dioxide emissions trajectories are based on van Vuuren et al. (2006) who provide a nationally downscaled dataset from the implementation of the global IPCC-SRES scenario B2 (IPCC, 2000) into the environmental assessment model IMAGE 2.2.

Our study assumes that the framework established under the Kyoto Protocol is retained for the 2012-2020 period. In particular, it is assumed that Kyoto mechanisms remain in place and that the Parties with commitments are restricted to those parties in Annex I that have commitments under Kyoto. Of course, these matters are currently the subject of negotiation. The 2007 UN Climate Change Conference's decision to launch negotiations on strengthening international actions to address climate change indicates that at a high level all Parties are willing to take actions beyond what they have already agreed to under the Convention and, for some Parties, under the Protocol. During and after the conference, many Annex I Parties made statements indicating their willingness to take on new and more demanding commitments.

Our modelling uses post-Kyoto emissions reduction targets for Annex I Parties ${ }^{5}$ based on public announcements through October 2008. Three of the largest Annex I players have yet to make declarations akin to those announced by most other Annex I parties: the United States, Russia and Ukraine. The United States is not participating in the Kyoto Protocol. President-elect Barak Obama, however advocates a national cap-and-trade scheme for emissions and a target of reducing US emissions to 1990 levels by 2020 (Obama and Biden, 2008).

Russia and the Ukraine are expected to have surplus AAUs at the end of the first commitment period. ${ }^{6}$ However, whether either would agree to deeper reductions than what they agreed under Kyoto is open to question.

The final assumptions about commitments are as follows. If countries announced two targets, with the higher depending on full international agreement, the lower target was chosen: The EU

\footnotetext{
${ }^{5}$ Consistent with Article 3.1 of the Kyoto Protocol, we refer to Parties assigned commitments under the Protocol as "Annex I Parties". The Article 3.1 reference to Annex I Parties is a reference to those Parties listed in Annex I of the United Nations Framework Convention on Climate Change. However, it should be noted that one Annex I Party, Turkey, was not assigned a target in Annex B of the Protocol.

${ }^{6}$ Refer to Box 11.1, p. 170, Eliasch, 2008.
} 
applies its target of 20 percent reduction from 1990 levels, rather than 30 percent; $^{7}$ the United States participates in a post-2012 agreement with a target of a 0 percent reduction in emissions relative to 1990 levels; Canada has a target of reducing emissions by 20 percent relative to 2006 levels by 2020 (Government of Canada, 2008); Japan has a target of reducing emissions by 14 percent relative to 2005 levels by 2020 (Fukuda, 2008); the Pacific OECD (Australia and New Zealand) has a target of 10 percent reduction relative to 2000 levels by $2020 ;{ }^{8}$ and the former Soviet Union has a target of no increase over current projections for 2020 emissions. ${ }^{9}$ An overview of baseline emissions and reduction targets is provided in Table 5 of Appendix A.

\subsection{Policy scenarios}

In the following, we present our policy scenarios of integrating REDD into the intergovernmental carbon market in 2020. The set of scenarios is summarised in Table 2.

First, the international emissions trading (IET) scenario represents intergovernmental trading of carbon permits at the core emission reduction commitments laid out in the previous section and, for comparability, abstracts from CDM access for industrialized countries. Our Base Case scenario includes the option of unlimited CDM offset credit imports by Annex I regions from undertaking emission reduction projects in the developing world as well as core commitments, but assumes a carbon market that develops without crediting reduced deforestation. Against this Base Case, scenario REDD describes the access for industrialized economies to carbon abatement options in tropical rainforest regions via REDD credits. This scenario tests the impact of unlimited REDD fungibility and represents the maximum credit exchange case. It also provides a metric against which the other policy scenarios can be measured.

\footnotetext{
${ }^{7}$ At the 2007 European Spring Council, the EU set a unilateral target of 20 percent emissions reductions relative to 1990 levels for 2020. "Provided that other developed countries commit themselves to comparable emission reductions and economically more advanced developing countries contribute adequately according to their responsibilities and respective capabilities" the target will be increased to 30 percent"(Council of the European Union, 2007).

${ }^{8}$ Note that this was the target initially proposed by Garnaut (2008). In the Final report, which was published after these parameters were selected, the recommended target is a 25 percent reduction relative to 2000 levels by 2020 "so long as the components of that agreement add up to the concentrations objective [of 450 ppm $\mathrm{CO}_{2} \mathrm{e}$ ]" (page xiv). If the objective is $550 \mathrm{ppm} \mathrm{CO}_{2} \mathrm{e}$ the Final report recommends a target of 10 percent below 2000 levels by 2020.

${ }_{9}$ As assumed in Anger and Sathaye (2007).
} 
Table 2 Carbon market scenarios for 2020

\begin{tabular}{|c|c|c|c|c|}
\hline $\begin{array}{l}\text { Institutional } \\
\text { scenario }\end{array}$ & $\begin{array}{c}\text { International } \\
\text { emissions } \\
\text { trading }\end{array}$ & $\begin{array}{l}\text { REDD } \\
\text { access }\end{array}$ & $\begin{array}{l}\text { REDD } \\
\text { restriction }\end{array}$ & $\begin{array}{c}\text { Commitment } \\
\text { levels }\end{array}$ \\
\hline IET & $\begin{array}{c}\text { Governmental } \\
\text { emissions } \\
\text { trading }\end{array}$ & \multirow[t]{2}{*}{ No } & \multirow[t]{2}{*}{-} & \multirow{3}{*}{ Core } \\
\hline$B A S E C A S E$ & \multirow{7}{*}{$\begin{array}{l}\text { Governmental } \\
\text { emissions } \\
\text { trading } \\
\text { including the } \\
\text { CDM }\end{array}$} & & & \\
\hline$R E D D$ & & \multirow{2}{*}{ Unlimited } & \multirow{2}{*}{ No } & \\
\hline$R E D D \_E X P$ & & & & Expanded \\
\hline$R E D D \_D E M$ & & \multirow{2}{*}{$\begin{array}{l}\text { Demand-side } \\
\text { restriction }\end{array}$} & \multirow{2}{*}{$\begin{array}{l}20 \% \text { of Annex I } \\
\text { region's } \\
\text { reduction } \\
\text { requirement in } \\
2020\end{array}$} & Core \\
\hline$R E D D \_D E M \_E X P$ & & & & Expanded \\
\hline$R E D D \_S U P$ & & \multirow{2}{*}{$\begin{array}{l}\text { Supply-side } \\
\text { Restriction }\end{array}$} & \multirow{2}{*}{$\begin{array}{l}\text { Equivalent (in } \\
\text { aggregate) in } \\
\text { supply terms to } \\
\text { the demand } \\
\text { restriction }\end{array}$} & Core \\
\hline$R E D D \_S U P \_E X P$ & & & & Expanded \\
\hline
\end{tabular}

Managed (or restricted) exchange of REDD units has been proposed to mitigate concerns about both the quality of REDD units and the impact of REDD units on emissions markets. One way of restricting the fungibility of REDD units is by imposing demand restrictions on market participants via a supplementarity requirement that limits the proportion of emission reduction commitments which can be offset by imported units (scenario REDD_DEM). Another approach to limit total credits from reduced deforestation available to the market is to impose supply restrictions, in which supplying regions are only able to export a specified quantity of units (scenario REDD_SUP). For our demand-side restriction, each region subject to commitments is restricted to importing a maximum of 20 percent of the required emissions reductions in 2020 . For the supply-side restriction scenario, the total export of REDD units is limited to 20 percent of the aggregate Annex I emission reduction requirements in 2020. Each REDD supply region is restricted to exporting a share of these units proportional to the REDD region's share of current term deforestation emissions. 
For our three REDD scenario cases, we also study increased demand for REDD units through expanded commitments (represented in scenarios REDD_EXP, REDD_DEM_EXP and REDD_SUP_EXP). In each scenario, for comparability Annex I commitment levels are expanded by an extent that yields a similar carbon price as our Base Case scenario, which assumed core commitments and the absence of REDD credits on the carbon market.

\section{Economic Background}

This section aims to explain the theoretical economic intuition of carbon-market impacts associated with the REDD policy scenarios described above. For brevity, we focus on the two most relevant cases: restrictions of supply and demand of REDD credits. We further study the implications of expanding commitments for these two market regulations.

Figure 1 describes the international market for REDD credits, denoting upward sloping credit supply by tropical rainforest regions with $\mathrm{S}$ and downward sloping credit demand by Annex I countries with D, as well as prices for REDD credits by $\mathrm{P}$ and quantities by Q, respectively. The carbon-market implications of restrictions on the demand for REDD credits are as follows. The implementation of a demand limit changes the demand curve to D', which results in a new market equilibrium with a lower price level and a lower quantity of REDD credits. This new market situation implies diminished producer rents for the supplying tropical rainforest regions (by the aggregate area $a+b$ in Figure 1) and augmented consumer rents for the purchasing Annex I countries (by the aggregate area $a-c$ in Figure 1). The overall deadweight loss through demand-side REDD market regulation is thus given by areas $b$ and $c$. 
Figure 1 Implications of restricting REDD credit demand (scenario REDD_DEM)

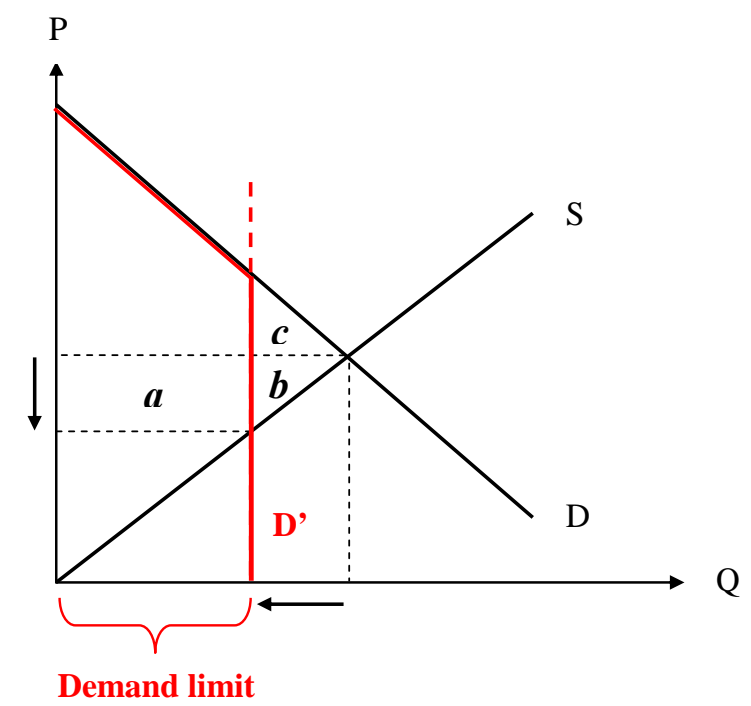

Figure 2 illustrates the consequences of restrictions on the supply of REDD credits. The implementation of a supply limit alters the supply curve to S', which results in a new market equilibrium with a higher price level and a lower quantity of REDD credits.

Figure 2 Implications of restricting REDD credit supply (scenario REDD_SUP)

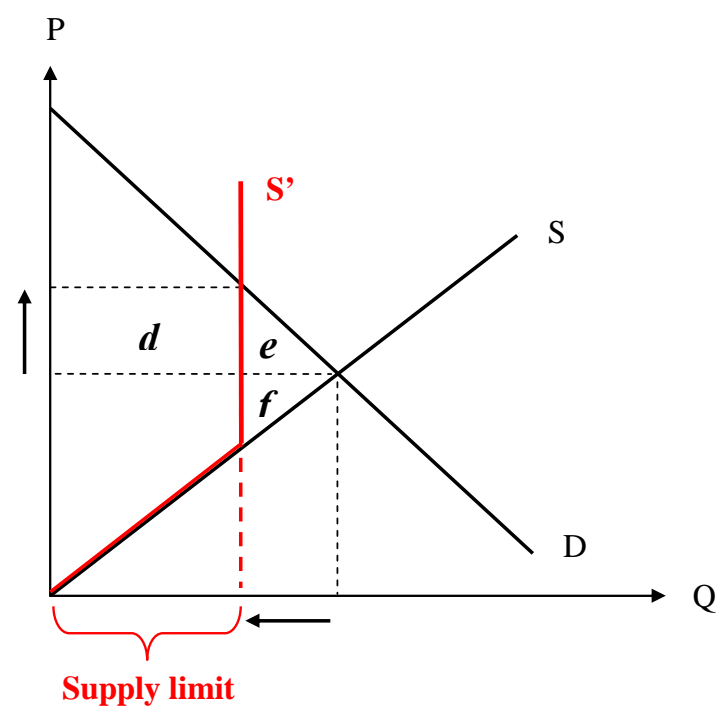


This new market situation implies higher producer rents of tropical rainforest regions (by the aggregate area $d$ - $f$ in Figure 2) and lower consumer rents of Annex I countries (by the aggregate area $d+e$ in Figure 2). The overall deadweight loss through supply-side REDD market regulation is thus given by areas $e$ and $f$.

We now turn to the carbon-market implications of expanding emission reduction commitments of Annex I countries for the two cases of market regulation. Figure 3 shows that for a carbon market with restrictions on demand for REDD credits, expanding Annex I commitment levels induces an upward shift of the REDD credit demand curve only within the range of the demand limit. As a consequence, the carbon-market equilibrium remains unchanged by the commitment expansion.

Figure 3 Implications of expanding Annex I commitments in the context of restricted REDD credit demand (scenario REDD_DEM_EXP)

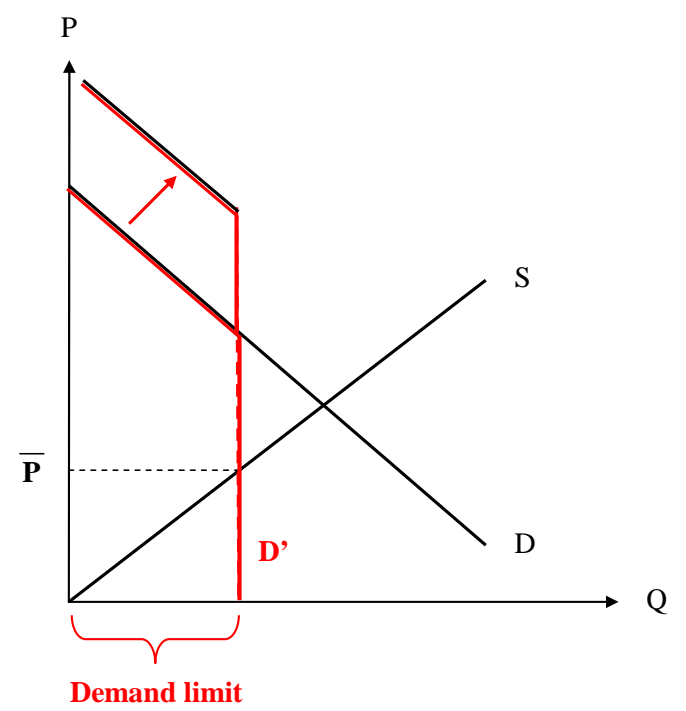

Finally, Figure 4 illustrates that in a carbon market with restrictions on the supply of REDD credits, expanding commitments induces an upward shift of the REDD credit demand curve to the new demand function D'. This results in a new market situation with a higher price level but - due to the supply limit - unchanged quantity of REDD credits. Consequently, the economic rents of tropical rainforest regions are augmented, while those of Annex I countries are diminished. 
Figure 4 Implications of expanding Annex I commitments in the context of restricted REDD credit supply (scenario REDD_SUP_EXP)

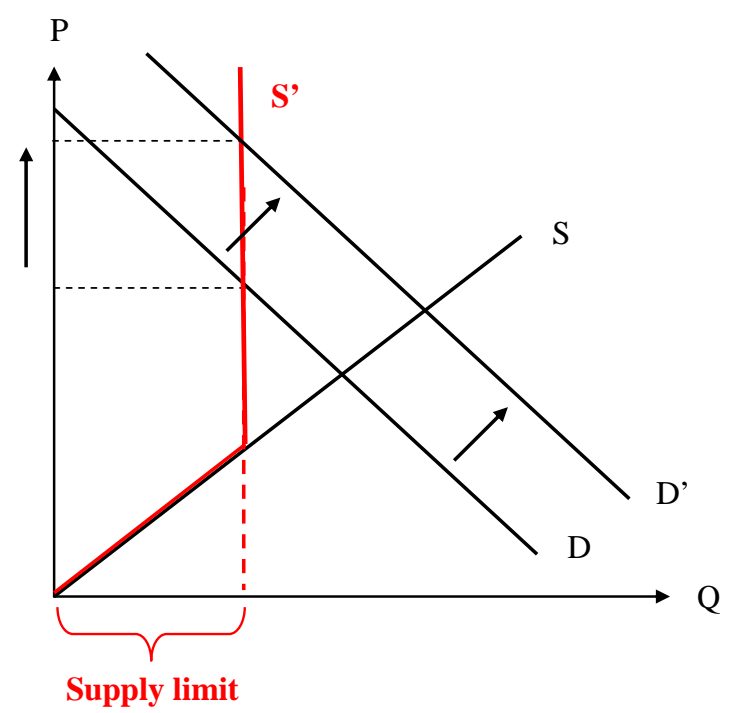

\section{Simulation results}

\subsection{Results and assessment for core commitments}

This section presents and discusses the simulation results for the core emissions reduction commitments of Annex I countries across the alternative policy scenarios. A complete set of quantitative results is presented in Appendix B.

We begin our quantitative analysis by assessing the carbon price impacts of alternative climate policy designs in the year 2020. The carbon constraints of Annex I countries result in an international permit price of roughly $€ 38$ per ton of $\mathrm{CO}_{2}$ if only governmental emissions trading is allowed (scenario IET) ${ }^{10}$. The global carbon price decreases to $€ 16$ under our Base Case when

\footnotetext{
${ }^{10}$ The commitment levels assumed for our modelling have been proposed by Parties with the expectation that inexpensive CDM emissions reductions will be available to offset some developed country emissions. As a consequence, the IET scenario is provided to illustrate the sensitivity of the model.
} 
we account for unlimited access by industrialized countries to the CDM, as the Annex I region is able to import carbon credits from low-cost emission abatement options in developing countries (scenario BASE CASE). This finding is consistent with previous studies (see e.g. Klepper and Peterson, 2006; Böhringer et al., 2005).

Against this background, Figure 5 illustrates the carbon price impacts of introducing REDD into a future climate policy regime. We find that the international permit price is reduced by 45 percent relative to the Base Case (which only includes the $\mathrm{CDM}$ ) to roughly $€ 9$ per ton of $\mathrm{CO}_{2}$ if Annex I countries are granted unlimited access to carbon credits from avoided deforestation (scenario $R E D D$ ). This price impact reveals the greater availability of carbon abatement options from REDD with lower marginal abatement costs than those CDM options used in the original carbon market equilibrium. This reflects the relatively low returns on land use and forest products in tropical regions and resulting low opportunity cost of reducing deforestation.. The increased competition on the supply side of the emissions market thus decreases the international permit price to the level of the REDD credit price.

Figure 5 Prices for international carbon permits and REDD credits by scenario

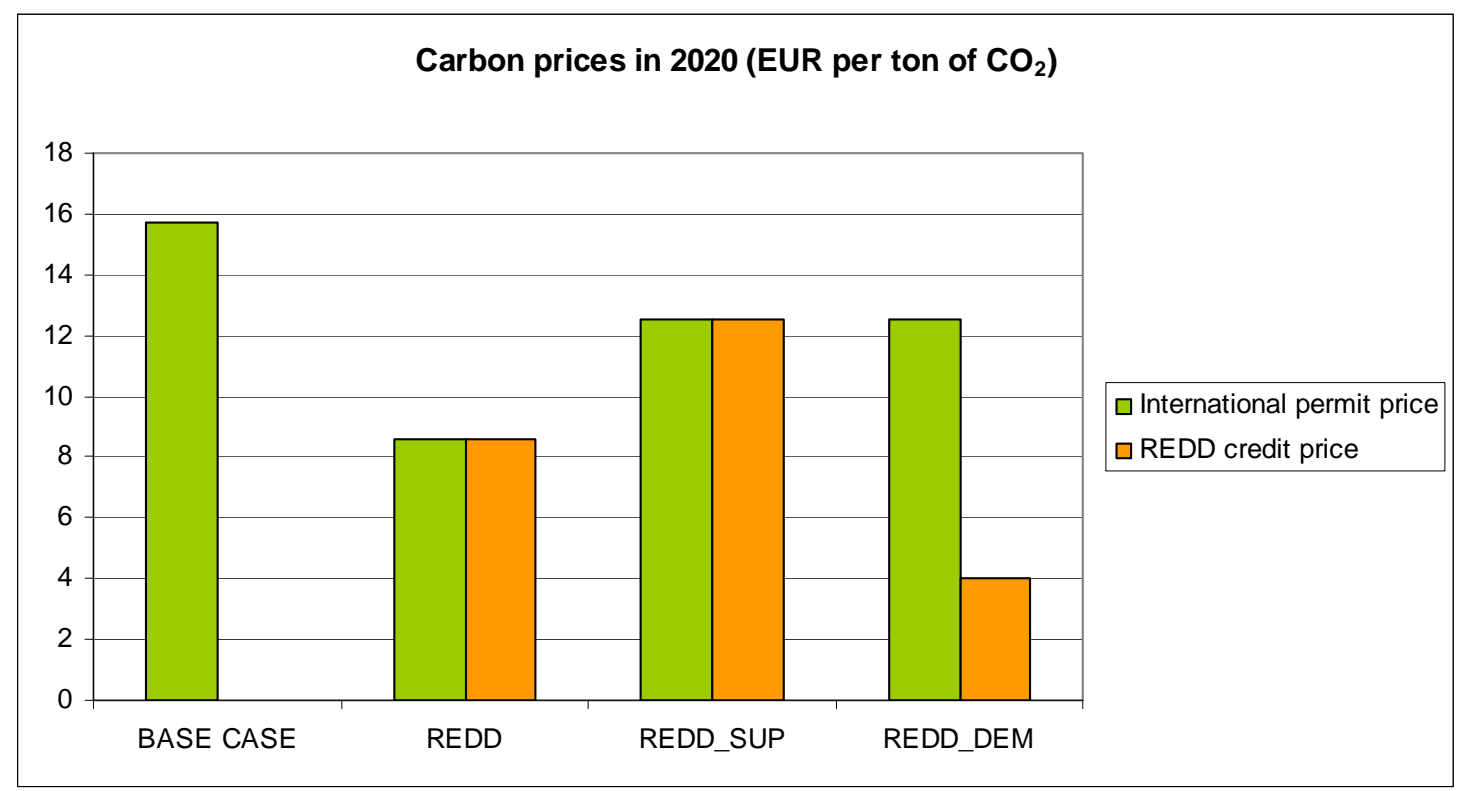

Figure 5 further shows that restricting supply or demand for REDD credits to 20 percent of each Annex I region's emission reduction requirement in the year 2020 limits the price-decreasing 
impacts of introducing REDD. We find that the international permit price generated under both the scenario REDD_SUP and scenario REDD_DEM is roughly $€ 13$ per ton of $\mathrm{CO}_{2}$, which represents a more moderate price decrease of 20 percent compared to the Base Case. The reason is that in both cases the amount of low-cost REDD credits on the market is lower than in the case of unlimited REDD fungibility. However, in the case of a demand-side restriction the REDD credit price decreases substantially to $€ 4$ per ton of $\mathrm{CO}_{2}$ : a REDD demand restriction thus drives a wedge between the REDD credit price and the international permit price.

We now turn to the total costs for complying with the assumed emissions reduction commitments across alternative policy designs in the year 2020. Figure 6 shows that total compliance costs reflect the carbon-price effects discussed above, including the cost-decreasing effect of unlimited CDM access. Most importantly, we find that integrating reduced deforestation on the international carbon market yields large economic efficiency gains, decreasing Annex I compliance costs by more than one third.

Figure 6 Aggregate compliance costs for the Annex I region by scenario

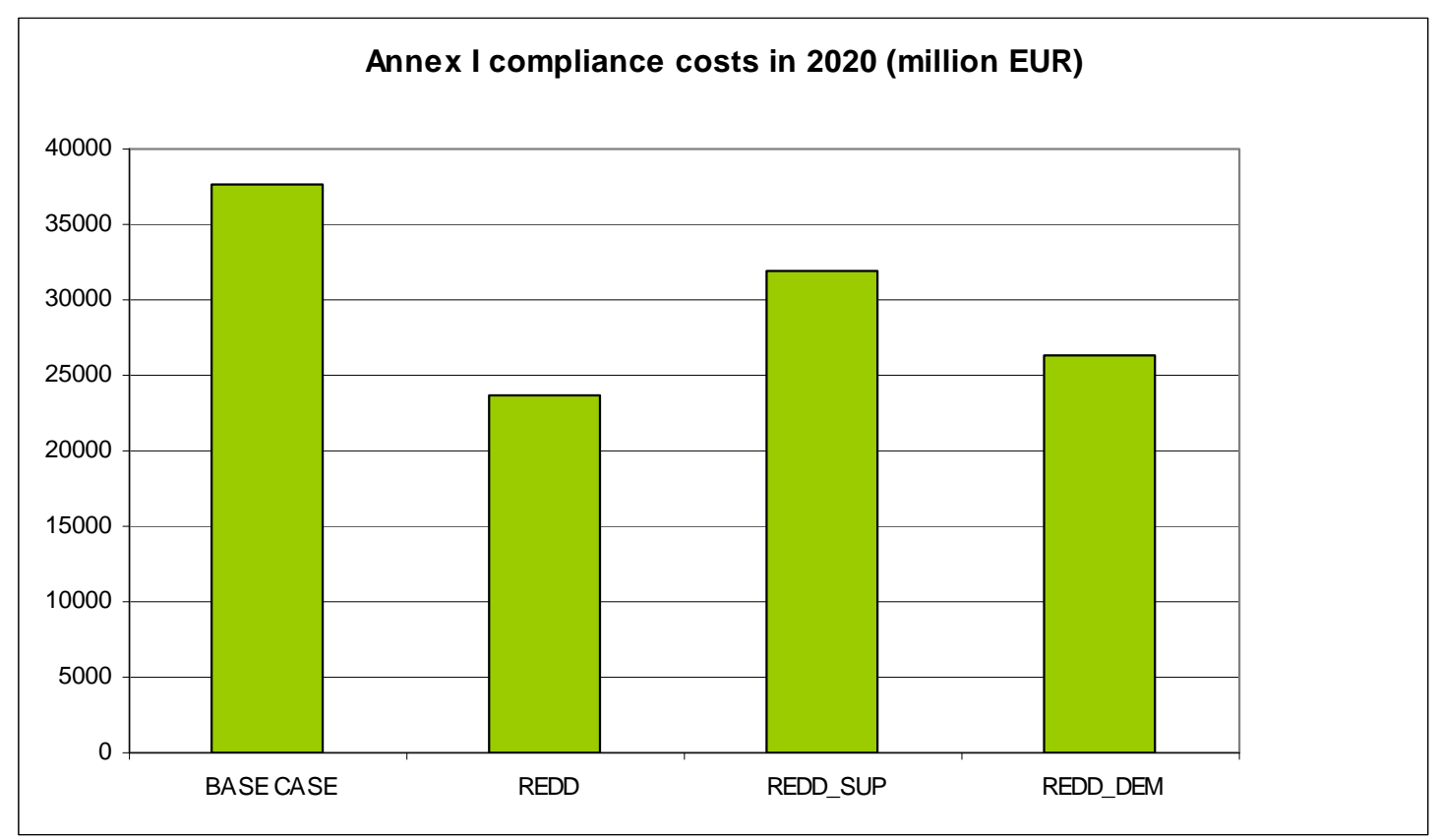


As noted above, the potential reduction in carbon price resulting from allowing unrestricted REDD access has raised concerns that this could cause critical delays in effecting crucial technological changes, such as the development of carbon capture and storage, necessary for achieving long term emissions targets. For this reason, restrictions on either the flows of REDD units onto emissions markets (supply restrictions) or the use of REDD unit for compliance purposes (demand restrictions or “supplementarity”) have been proposed.

Against this background, Figure 6 and Figure 7 together indicate that mitigation of REDD carbon price impacts through the restriction of REDD supply or demand occurs at the expense of economic efficiency. While the total compliance costs for industrialized countries are still diminished through the introduction of REDD as compared to CDM access only, the cost savings from REDD are considerably lower when REDD supply and demand are regulated. However, Figure 6 shows that compliance costs are significantly lower in the case of limited REDD demand as compared to the case of restricted supply - Annex I cost savings from REDD amount to 30 percent for a demand limit, but only 15 percent for the supply limit. This central result can be explained as follows: While restricting REDD demand decreases the REDD credit price, thereby reducing the producer surplus for tropical rainforest regions and increasing the consumer surplus of Annex I regions, restricting REDD supply has the opposite effect (compare again Figure 1 and Figure 2). In other words, the wedge between the REDD and the international permit price caused by a demand-side restriction decreases the total costs of REDD credit imports for Annex I regions and thus induces lower total compliance costs than a supply-side regulation. In conclusion, of the two options for maintaining the international permit price, the option that best limits Annex I compliance costs is restricting REDD demand. However, demand restriction is the less desirable option for developing countries because they earn less from REDD activity, as shown in Figure 7. 
Figure $7 \quad$ Net economic benefits (revenues less costs) by rainforest region and scenario

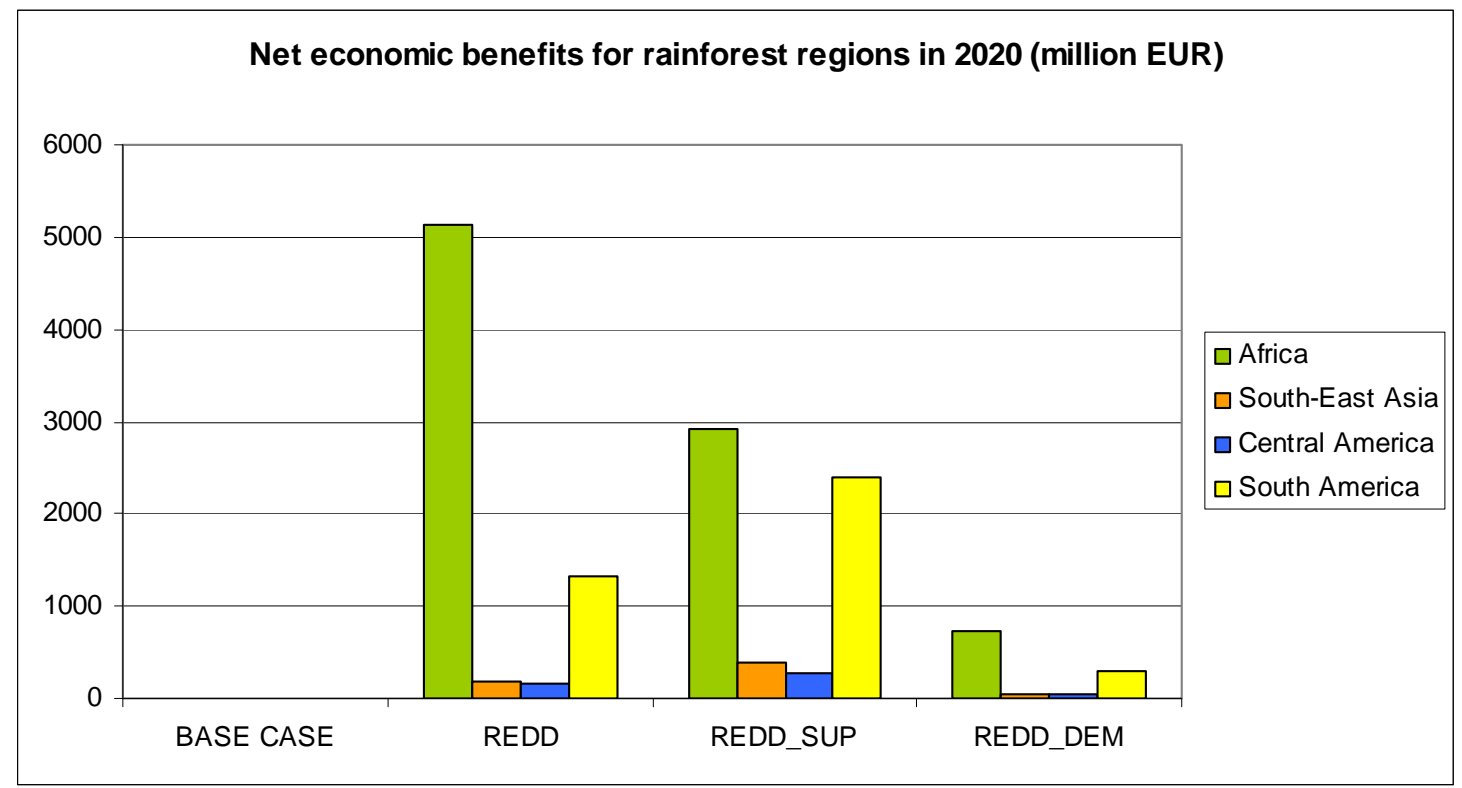

We now discuss the implications for the international trade of carbon permits. Figure 8 presents regional net REDD credit exports across our policy scenarios. It shows that for unlimited REDD fungibility, Africa is the dominant credit exporter to Annex I countries, followed by South America. In comparison, the tropical regions of South-East Asia and Central America play a rather minor role on the market for REDD credits. The reason for Africa's dominance is the relatively low opportunity costs of abatement in this region combined with a large quantitative potential of reducing deforestation (in terms of forest area and projected deforestation activity). ${ }^{11}$

The situation is somewhat different under restricted REDD supply which results in a REDD price equal to the international permit price. This results in greater REDD activity in the regions other than Africa because competition between REDD regions is restricted (each supplying region has its own cap) and a higher resultant price leads to increased REDD activity in other regions. Under this scenario REDD credits from Africa are roughly equal to South American exports and the level of REDD activity relative to business-as-usual is similar in all tropical rainforest

\footnotetext{
11 Some readers may note that not all nations currently possess sufficient institutional or technological capacity to participate effectively in a REDD regime. The potential inability to develop REDD programs in some locales needs to be taken into account when considering the large number of REDD credits generated from Africa in our modelling.
} 
regions. Table 7 in Appendix B presents the corresponding regional reductions of carbon emissions.

Figure $8 \quad$ Net exports (exports less imports) of REDD credits by region and scenario

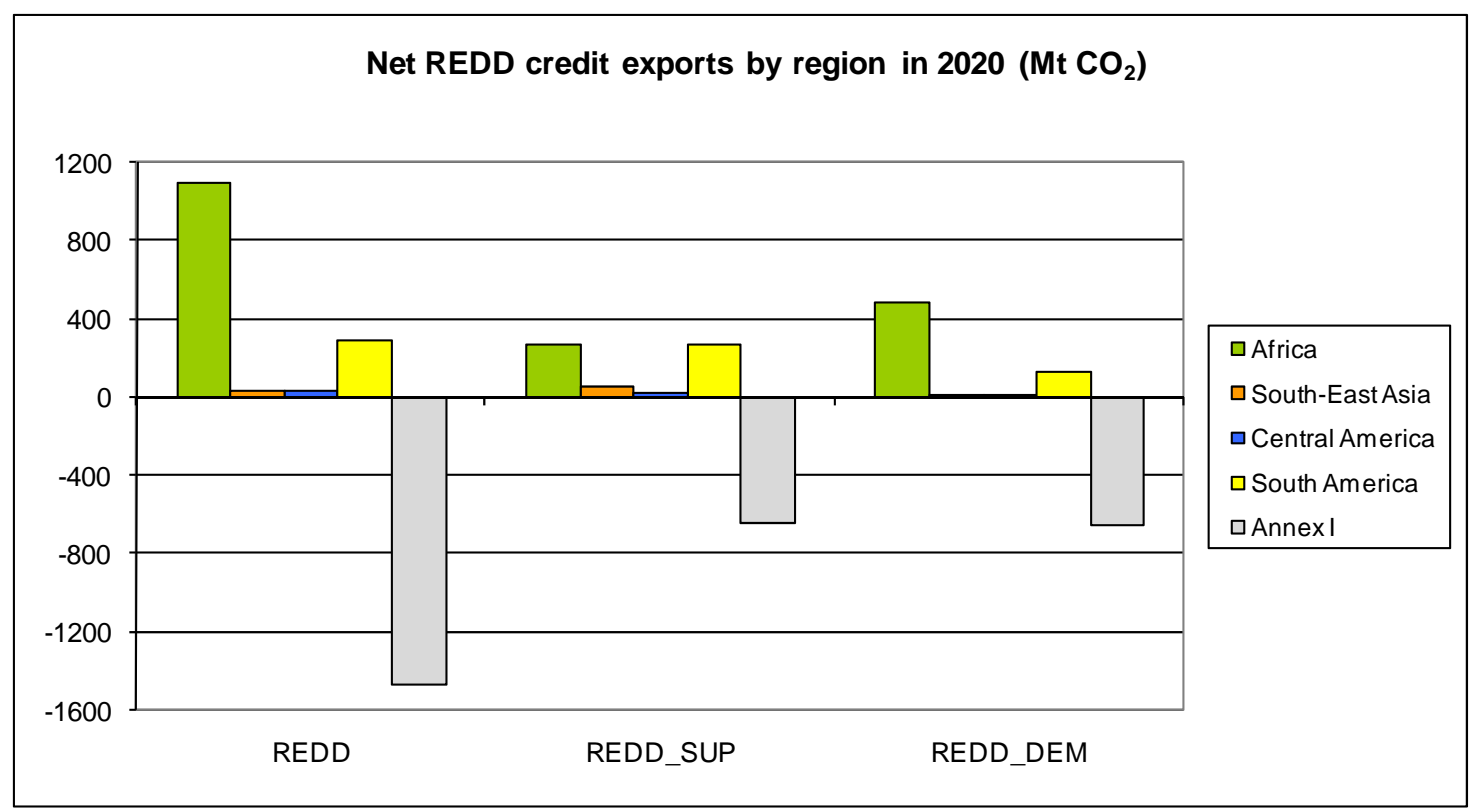

As well as improving overall efficiency by reducing Annex I compliance costs, the other key impact of REDD is to reduce the activity of the CDM through increased credit supply competition, as shown in Figure 9. Base Case CDM credit exports are reduced by around a half under unrestricted REDD access and by around a quarter under the supply and demand restrictions. This occurs because some REDD emissions abatement occurs at a lower marginal cost than conventional CDM abatement options.

The substitution of REDD exports to Annex I countries for CDM credits translates into substantially lower net benefits to CDM host regions, as shown in 0 of in Appendix B. In particular, under the unrestricted REDD access scenario (Scenario REDD) net economic benefits to CDM host regions drop to roughly one third of that for the Base Case without REDD, and decrease to less than two thirds in the case of supply or demand restrictions. This suggests that the combination of unlimited REDD access with no increase in Annex I commitments may 
significantly reduce CDM activity because of the greater economic attractiveness of REDD for Annex I regions.

Figure $9 \quad$ Net credit exports (exports less imports) of CDM host regions by scenario

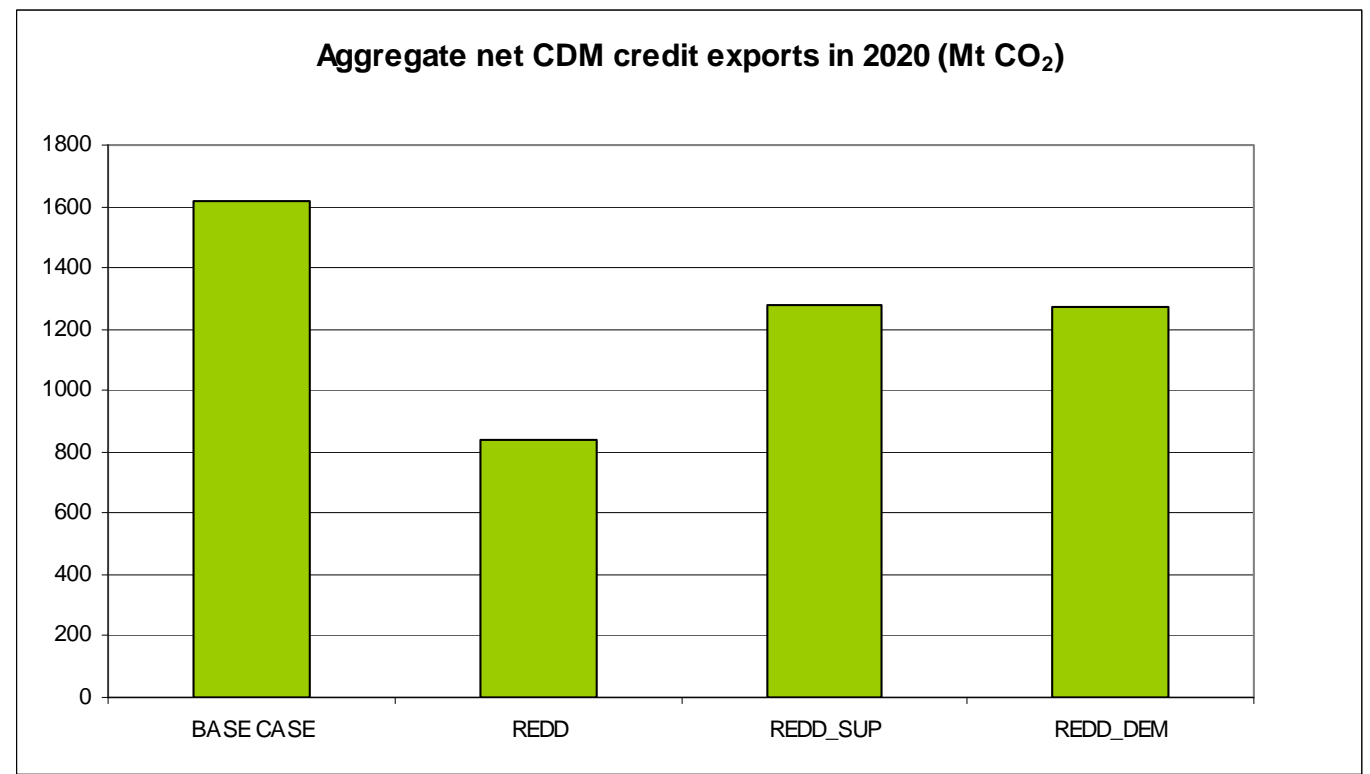

\subsection{Results for expanded commitments}

This section presents and discusses the simulation results for expanded emission reduction commitments of Annex I countries across the alternative policy scenarios. Our central findings are illustrated in the figures set out in this section (the complete set of quantitative results is presented in Table 5).

Taking advantage of the low cost of REDD abatement allows Annex I commitments to be extended by a significant degree with a consequent increase in emission reductions. As noted in Section 2.3, we have maintained the international carbon permit price at the same level in our expanded commitments scenarios as under the Base Case.

Relative to our Base Case, unrestricted access to REDD allows Annex I commitments to increase by 62 percent. This results in an average Annex I emissions target 32 percent lower than business as usual, or 24 percent lower than 1990 levels. This is approaching the lower end of the 
range of 25-40 percent reductions vs. 1990 levels identified by the IPCC as necessary to achieve a 450ppm $\mathrm{CO}_{2}$ e concentration target (Gupta et al., 2007).

Figure 10 shows expanded commitment levels for each of our policy scenarios. With REDD unit supply or demand restrictions Annex I commitments are only increased by 20 percent relative to the Base Case for constant international permit prices.

Figure 10 Core and expanded Annex I commitments levels by scenario

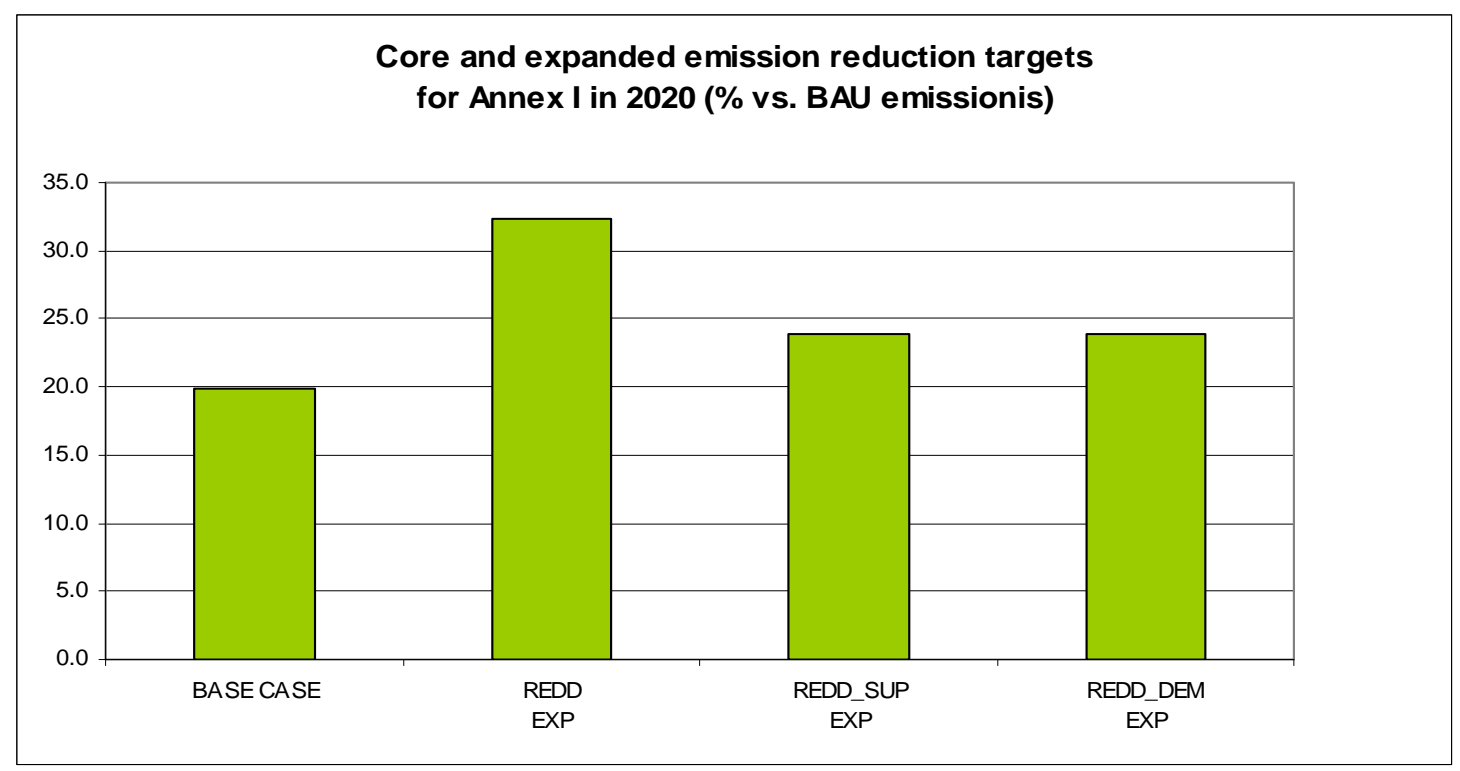

Despite the constant carbon price across scenarios, expanding commitments increases compliance costs for Annex I as more units are purchased. Figure 11 shows that compliance costs for expanded commitments with unrestricted REDD access are approximately double the compliance costs in the Base Case. With REDD demand and supply restrictions fewer units are purchased leading to compliance costs around a third lower than with unrestricted access to REDD - but abatement is lower as well. The compliance cost of expanded targets is around a fifth lower with REDD demand restrictions as compared with supply restrictions. As previously, this is because the impact of REDD demand restrictions is to lower the REDD unit price - as shown in Figure 12 - and since the REDD unit price is not increased by expanded targets, the overall cost of purchasing units is lower. 
Figure 11 Aggregate compliance costs for the Annex I region by scenario

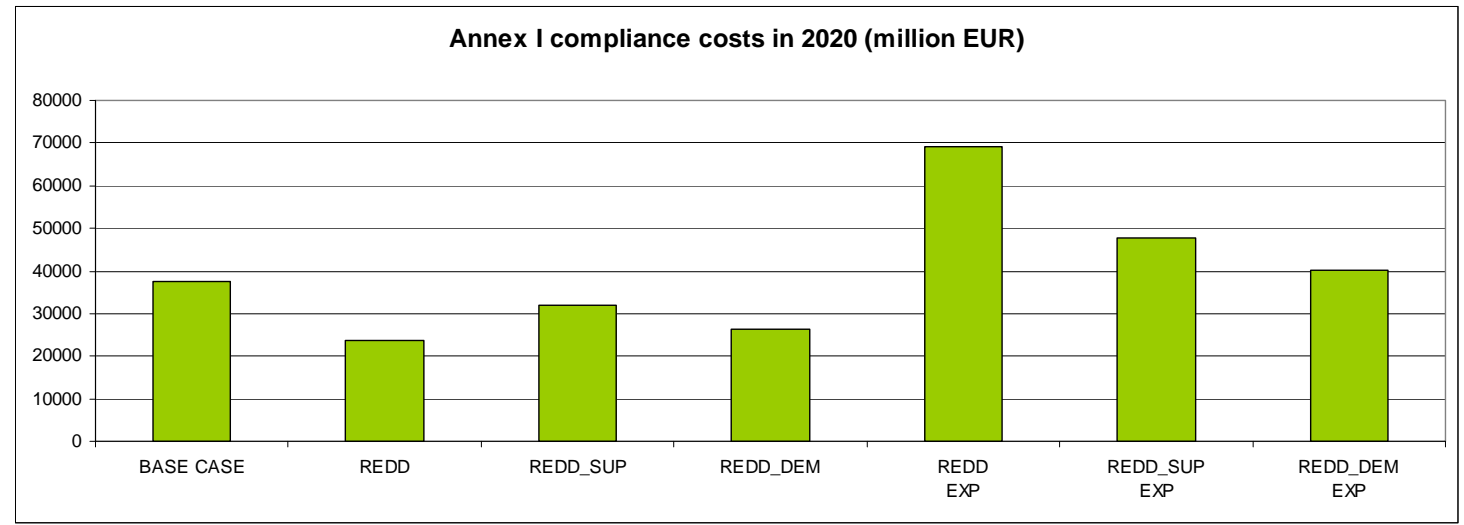

Figure 12 Prices for international carbon permits and REDD credits by scenario

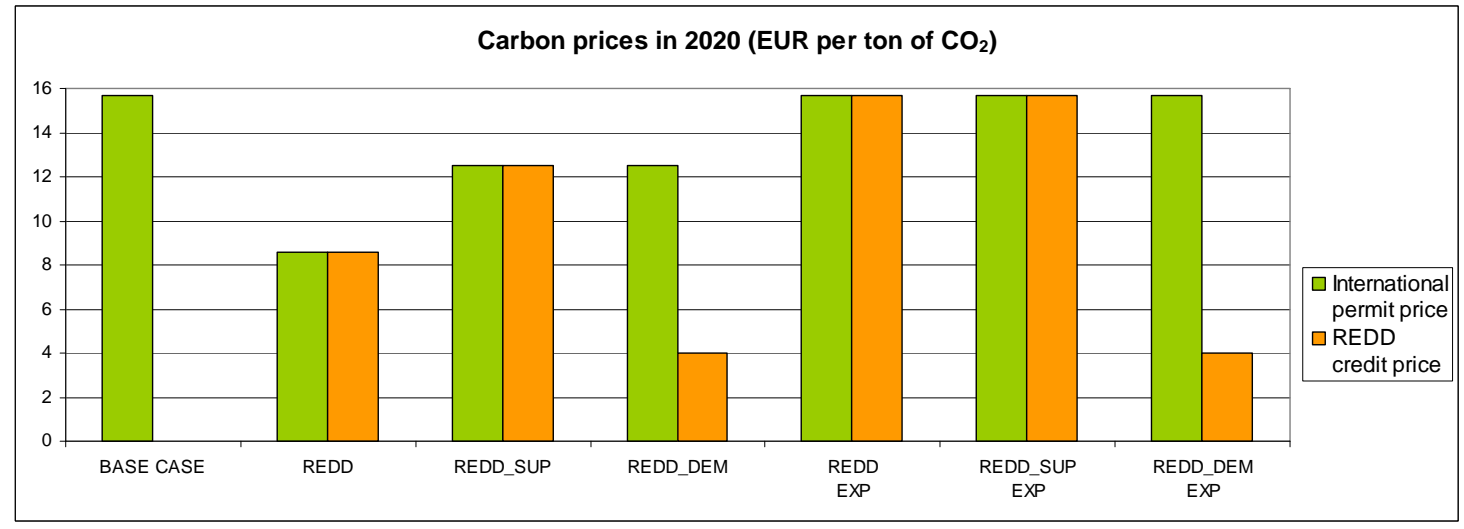

The impact of increased Annex I commitments under the unrestricted REDD access scenario is to increase exports of REDD credits relative to the core commitments scenario (scenario REDD), as shown in Figure 13. This is because the higher unit price means abatement that was not economic under core commitments becomes economic under the higher emissions price that results from increased commitments.

Figure 11 also shows that REDD credit exports remain fixed with expanded commitments under both the supply and demand restrictions. These results correspond to the economic intuition in Figure 3 and Figure 4 in Section 3. Figure 3 illustrated that the impact of expanded commitments with a demand restriction is to shift the demand curve outward within the range of the restriction, resulting in unchanged cost and exports of REDD units. Figure 4 showed the effect of a supply 
restriction is an outwards shift of the REDD demand curve but with supply unchanged, which results in an increase in the price for REDD units. The effect of the increased price under the latter scenario is a transfer of rents from Annex I to REDD-supplying nations.

Figure 13 Net exports (exports less imports) of REDD credits of rainforest regions by scenario

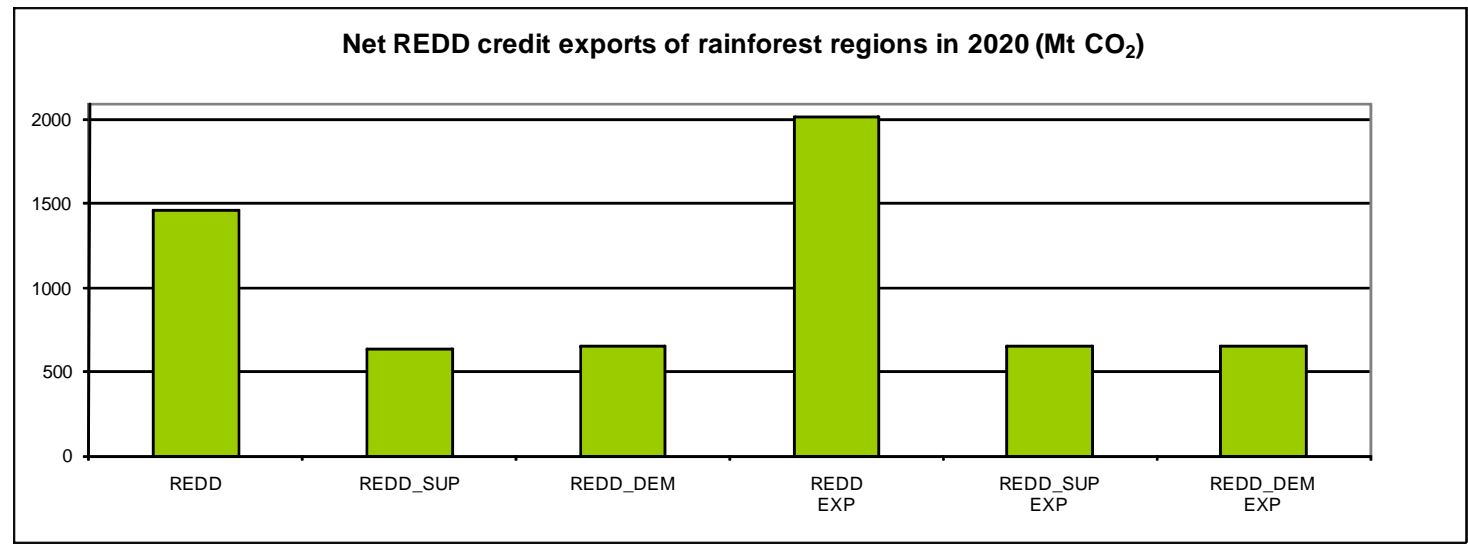

\subsection{Sensitivity analysis}

In the introduction we emphasized the importance of uncertainties around the cost and scope of REDD credit supply. As these uncertainties are derived from both REDD policy choices and the uncertainties in the forestry data input we have utilised, we now provide a sensitivity analysis around REDD marginal abatement cost. The corresponding simulation results are presented in Appendix C.

The analysis illustrates the dynamics of the carbon market in 2020 over a broad range of REDD costs. The low-cost scenario (REDD_MAC) halves the marginal costs of REDD units supplied at any given REDD quantity as compared to the REDD scenario, while the high-cost scenario $\left(R E D D \_M A C+\right)$ doubles the cost of supplied REDD units at any given REDD quantity compared to the REDD scenario. These two scenarios are otherwise identical to the REDD scenario and thus demonstrate the impact of a range of REDD cost assumptions on carbon prices, associated compliance costs, and transfers. ${ }^{12}$

\footnotetext{
12 The double/half supply levels were selected, in part, to be consistent with modelling done by the Environmental Defense Fund (Cabezas and Keohane, 2008).
} 
We find that international carbon permit prices are relatively robust to the tested changes in REDD supply functions. As shown in Table 13, the impact on the international carbon price is within the +/- 20 percent range-a level that is moderate given the large swing in REDD supply costs. This holds true for both core commitments and expanded commitments. The impact on CDM host countries, however, is greater with CDM exporters receiving a windfall of an additional 50 percent net economic benefit with REDD supply costs increased, and losing 40 percent of the economic benefit of the REDD scenario with REDD supply costs decreased. Impacts on CDM supplying regions are somewhat less dramatic under expanded commitments with the net economic benefit within a $+/-35$ percent range of the benefit under the REDD expanded commitments scenario. The corresponding total compliance cost impacts are provided in Table 14.

In order to account for different levels of supply under expanded targets, two additional scenarios are modelled at the expanded commitment level for unlimited REDD access (i.e. at a 62\% expansion of core commitments). Again, marginal REDD supply costs are halved and doubled at each REDD quantity in these scenarios, which are denoted REDD_MAC_EXP and $R E D D \_M A C+$ _EXP respectively. We find that also for expanded commitments the carbon price impacts of alternative supply costs remain within the 20 percent range.

\section{Conclusions}

Without alterations to currently proposed Annex I commitments, an unrestricted integration of REDD units into the post-Kyoto international emissions market may approximately halve the international price of carbon in 2020. While this reduction leads to substantial compliance cost savings for developed countries in the short term, the incentives for increased domestic abatement are decreased in the medium term and development of clean infrastructure and technologies may be delayed.

Another potential barrier to unrestricted integration could include opposition from CDM supplying nations, who as the modelling shows stand to lose a large portion of their net economic benefit from the CDM compared to the Base Case. Some developed countries may also oppose 
the significant wealth transfers to non-Annex I nations when these nations are not subject to emission reduction commitments.

Demand-side and supply-side restrictions on the import of REDD units into compliance markets can support prices, but would fail to encourage further progress toward more ambitious GHG reduction goals by simultaneously restricting economic efficiency. While demand-side restrictions will please the cost conscious in developed countries, maintaining a reasonably high international price of carbon while enabling REDD units to be acquired at a mere third of that price may cause disaffection among supplying nations.

As negotiators prepare for Copenhagen 2009, consideration should be given to another option: expanding commitments beyond what Annex I Parties may currently be contemplating. The cost savings to Annex I Parties which would occur with REDD integration could justifiably be reinvested in deeper commitments.

In investigating a scenario which could fully mitigate the concerns over lost CDM income and a dampening of the international carbon price signal, we describe an option which is calibrated to yield a carbon price similar to what occurs in the Base Case. While the additional 60 percent reduction from core commitments ${ }^{13}$ for Annex I is ambitious, it takes full advantage of the efficiency gains of intersectoral trading between domestic Annex I, CDM, and REDD emissions reductions. The result is GHG mitigation which approaches the lower end of the IPCC range of a 25-40 percent reduction in emissions allowances to Annex I nations compared to 1990 levels to stabilise atmospheric carbon at 450ppm $\mathrm{CO}_{2} \mathrm{e}$ (Gupta et al, 2007).

The total costs for such expanded commitments are considerable. Annex I compliance costs increase approximately 85 percent with additional reductions of this magnitude. Transfer payments from Annex I to CDM and REDD nations increase to a level two-and-a-half times that with core commitments. Clearly, a lower expansion of Annex I targets would be possible at constant compliance costs.

\footnotetext{
${ }^{13}$ Our Base Case assumed aggregate reductions (includes US) of 20 percent from 2020 BAU (-10 percent vs. 1990) levels while our expanded commitments scenario results in reductions of 32 percent from 2020 BAU (-24 percent vs. 1990). The Base Case reductions are at the upper end of the 550ppm CO2e reduction scenario, and best represent a level of effort in line with no action to depart from baseline by non-Annex I nations.
} 
The opportunities presented are significant; however caution is required when considering the results of modelling efforts in general. While adequate for comparing alternative policy scenarios, our model is not deterministic and does not aim at predicting prices explicitly. Updating this model with improved understanding of forest and domestic abatement costs will further improve its currency, but factors such as technological change or feedback-effects on non$\mathrm{CO}_{2}$ markets are beyond this study.

While the modelling in this paper illustrates the benefits and costs of incorporating REDD into international carbon markets, whether a viable REDD supply will actually materialise still remains uncertain at the time of writing. Significant concerns around the permanence of mitigation and the environmental integrity of REDD units will need to be successfully addressed in the design of a REDD regime. Even once these issues have been addressed, natural factors and market conditions will impact the supply of REDD units.

This study shows that if these issues are addressed, REDD provides a large opportunity for both economic efficiency gains and significant future emission reductions for combating global climate change. Annex I emissions reduction commitments can increase to close to the range recommended by the IPCC at carbon price levels that would prevail with access to the CDM only, if Annex I Parties have unrestricted access to REDD units for meeting their commitments. However, Annex I compliance costs would increase significantly as a result of the substantial transfer of funding to tropical forest countries through the purchase of REDD units. Compliance costs could, of course, be limited with less ambitious expansions of Annex I targets.

This raises an essential issue for the post-2012 negotiations: are Annex I Parties willing to increase their commitments (and financial transfers to developing countries) while absorbing substantial increases in compliance costs? Unrestricted access to REDD coupled with Annex I targets that reflect this large source of emission reductions would provide significant benefits in terms of increased mitigation and potential poverty alleviation. However, Annex I Parties may not be willing to agree to the increased costs (or the level of commitments) without corresponding concessions from developing countries. 


\section{References}

Anger, N., Sathaye, J., 2008. Reducing Deforestation and Trading Emissions: Economic Implications for the Post-Kyoto Carbon Market. ZEW Discussion Paper No. 08-016, Mannheim.

Anger, N., 2008. Emissions Trading Beyond Europe: Linking Schemes in a Post-Kyoto World. Energy Economics 30(4), 2028-2049.

Antinori, C., Sathaye, J., 2007. Assessing Transaction Costs of Project-based Greenhouse Gas Emissions Trading. Lawrence Berkeley National Laboratory Formal Report LBNL57315.

Böhringer, C., Hoffmann, T., Lange, A., Löschel, A., Moslener, U., 2005. Assessing Emission Allocation in Europe: An Interactive Simulation Approach. The Energy Journal 26 (4), 122.

Cabezas, P.P., Keohane, N., 2008. Reducing Emissions from Deforestation and Degradation (REDD): Implications for the Carbon Market. White paper. Environmental Defense Fund, New York.

Combes Motel, P., Pirard, R., Combes, J.-L., 2009. A methodology to estimate impacts of domestic policies on deforestation: Compensated Successful Efforts for "avoided deforestation” (REDD). Ecological Economics 68 (3), 680-691.

Council of the European Union, 2007. Brussels European Council, 8/9 March 2007, Presidency Conclusions, Brussels, 2 May 2007.

Criqui, P., Mima, S., Viguier, L., 1999. Marginal abatement costs of $\mathrm{CO}_{2}$ emission reductions, geographical flexibility and concrete ceilings: an assessment using the POLES model. Energy Policy 27 (10), 585-601.

Eliasch, J., 2008. Climate Change: Financing Global Forests: The Eliasch Review. United Kingdom Office of Climate Change (OCC).

European Commission, 2008. Addressing the challenges of deforestation and forest degradation to tackle climate change and biodiversity loss. Communication from the Commission to 
the European Parliament, the Council, the European Economic and Social Committee and the Committee of the Regions. 17 October 2008.

European Union, 2008. Proposal for a Directive of the European Parliament and of the Council amending Directive 2003/87/EC so as to improve and extend the greenhouse gas emission allowance trading system of the Community. Communication COM(2008) 30 final, European Commission, Brussels.

FAO, 2007. State of the World's Forests, Food and Agriculture Organization of the United Nations, Rome.

Fukuda, Y., 2008. Speech to Japan National Press Club outlining "Fukuda Vision: In pursuit of a low carbon society”. 14 June 2008.

Garnaut, R., 2008. The Garnaut climate change review: Final report.

Government of Canada, 2008. Turning the corner: Regulatory Framework for Industrial Greenhouse Gas Emissions.

Gupta et al., Polices, Instruments and Co-operative Arrangements in Climate Change 2007: Mitigation, Contributions of Working Group III to the Fourth Assessment Report of the Intergovernmental Panel on Climate Change (Metz et al. (eds.)), Cambridge University Press, 2007, Chapter 13, Box 12.7; IPCC, AR4 Synthesis Report, 2007, Topic 5, Table 5.1.

IPCC, 2000. Emissions Scenarios: Special Report of the Intergovernmental Panel on Climate Change. Cambridge University Press, Cambridge.

Klepper, G., Peterson, S., 2006. Emissions trading, CDM, JI, and more: the climate strategy of the EU. The Energy Journal 27 (2), 1-26.

Obama, B., Biden, J., $2008 . \quad$ Promoting a healthy environment. http://www.barackobama.com/pdf/issues/EnvironmentFactSheet.pdf

Sathaye, J et al., 2008. Updating carbon density and opportunity cost parameters in deforesting regions in the GCOMAP model. International Energy Solution (IES)

Sathaye, J., Makundi, W., Dale, L., Chan, P., Andrasko, K., 2006. GHG Mitigation Potential, Costs and Benefits in Global Forests: A Dynamic Partial Equilibrium Approach. The 
Energy Journal, Multi-Greenhouse Gas Mitigation and Climate Policy Special Issue, 95124.

Sathaye, J., Makundi, W., Dale, L., Chan, P., Andrasko, K., 2005. Estimating Global Forestry GHG Mitigation Potential and Costs: A Dynamic Partial Equilibrium Approach. Lawrence Berkeley National Laboratory Formal Report LBNL-55743.

Sohngen, B. and R. Mendelsohn, 2003. An optimal control model of forest carbon sequestration, American Journal of Agricultural Economics 85 (2) 448-457.

Tavoni, M., Sohngen, B. and V. Borsetti, 2007. Forestry and the Carbon Market Response to Stabilize Climate, Fondazione Eni Enrico Mattei Nota di Lavoro 15.2007.

Van Vuuren, D., Lucas, P., Hilderink, H., 2006. Downscaling drivers of global environmental change scenarios: Enabling use of the IPCC SRES scenarios at the national and grid level. Netherlands Environment Assessment Agency (MNP).

Weyant JP, Hill J, 1999. Introduction and Overview. The Energy Journal, special issue on The costs of the Kyoto Protocol: a multi-model evaluation, vii-xliv. 


\section{Appendix A Marginal abatement cost functions and emission market assumptions}

Table 3 Marginal abatement cost coefficients for conventional abatement options (€2005)

\begin{tabular}{|c|c|c|c|c|c|c|}
\hline \multirow{2}{*}{ Region } & \multicolumn{3}{|c|}{ Energy-intensive sectors (EIS) } & \multicolumn{3}{|c|}{$\begin{array}{l}\text { Non-energy-intensive sectors } \\
\text { (NEIS) }\end{array}$} \\
\hline & $\boldsymbol{\beta}_{1, E I S, r}$ & $\boldsymbol{\beta}_{2, E I S, r}$ & $\boldsymbol{\beta}_{3, E I S, r}$ & $\beta_{1, N E I S, r}$ & $\boldsymbol{\beta}_{2, N E I S, r}$ & $\beta_{3, N E I S, r}$ \\
\hline Austria & 21.1480 & -3.3392 & 0.8094 & 11.4095 & 2.8620 & -0.1012 \\
\hline Belgium & 2.8430 & -0.0984 & 0.0026 & 5.8176 & 0.1881 & 0.0176 \\
\hline Denmark & 11.1840 & -0.5817 & 0.0235 & 59.6656 & -12.7515 & 5.7710 \\
\hline Finland & 3.0710 & -0.0566 & 0.0032 & 75.2956 & -14.0624 & 1.5541 \\
\hline France & 0.9439 & -0.0078 & 0.0002 & 1.5191 & 0.0784 & -0.0007 \\
\hline Germany & 0.3668 & -0.0017 & 0.0000 & 0.9417 & 0.0111 & 0.0000 \\
\hline Greece & 1.8843 & -0.0118 & 0.0005 & 30.8964 & -1.6083 & 0.3375 \\
\hline Ireland & 3.0683 & -0.1585 & 0.0110 & 23.4662 & -0.3972 & 0.2788 \\
\hline Italy & 0.9413 & 0.0036 & 0.0001 & 2.5992 & 0.1511 & -0.0005 \\
\hline Netherlands & 0.8665 & 0.0393 & -0.0004 & 10.9863 & -0.4063 & 0.1088 \\
\hline Portugal & 11.0386 & -0.5740 & 0.0175 & 56.1921 & -9.2007 & 2.4941 \\
\hline Spain & 0.8090 & -0.0097 & 0.0002 & 10.3924 & -0.4192 & 0.0137 \\
\hline Sweden & 7.7433 & -0.2814 & 0.0102 & 12.5684 & 1.7070 & 0.3807 \\
\hline United Kingdom & 0.4066 & -0.0022 & 0.0000 & 1.4731 & 0.0244 & -0.0001 \\
\hline Eastern Europe & 0.1466 & 0.0001 & 0.0000 & 0.7554 & 0.0008 & 0.0000 \\
\hline Canada & 0.2766 & 0.0007 & 0.0000 & 0.8316 & 0.0044 & 0.0001 \\
\hline Japan & 0.2666 & 0.0023 & 0.0000 & 1.3130 & 0.0313 & -0.0001 \\
\hline \begin{tabular}{|l} 
Former Soviet \\
Union \\
\end{tabular} & 0.0218 & 0.0002 & 0.0000 & 0.1075 & 0.0004 & 0.0000 \\
\hline Pacifc OECD & 0.7244 & -0.0094 & 0.0001 & 1.8636 & -0.0315 & 0.0005 \\
\hline United States & 0.0245 & 0.0000 & 0.0000 & 0.1453 & 0.0000 & 0.0000 \\
\hline Brazil & 11.5525 & -0.0631 & 0.0001 & 4.1163 & 0.0006 & 0.0004 \\
\hline China & 0.0129 & 0.0000 & 0.0000 & 0.3052 & -0.0004 & 0.0000 \\
\hline India & 0.0960 & -0.0001 & 0.0000 & 2.2685 & -0.0346 & 0.0008 \\
\hline Mexico & 0.0116 & 0.0191 & -0.0001 & 0.3852 & 0.0204 & -0.0001 \\
\hline South Korea & 0.3405 & -0.0011 & 0.0000 & 4.1598 & -0.0027 & 0.0010 \\
\hline
\end{tabular}

Table $4 \quad$ Marginal abatement cost coefficients for reduced deforestation (€2005)

\begin{tabular}{|l|r|r|r|}
\hline \multicolumn{1}{|c|}{ Region } & $\boldsymbol{\beta}_{\boldsymbol{1 , \boldsymbol { r }}}$ & $\boldsymbol{\beta}_{2, \boldsymbol{r}}$ & \multicolumn{2}{c|}{$\boldsymbol{\beta}_{3, \boldsymbol{r}}$} \\
\hline Africa & 0.01807 & -0.00011 & 0.00000 \\
\hline South-East Asia & 0.20949 & -0.00095 & 0.00002 \\
\hline Central America & 0.23116 & -0.00114 & 0.00002 \\
\hline South America & 0.02841 & -0.00002 & 0.00000 \\
\hline
\end{tabular}


Table 5 Baseline emissions and emission reduction targets by region in 2020 (announced commitments in bold numbers)

\begin{tabular}{|c|c|c|c|c|c|c|c|c|}
\hline Region & $\begin{array}{c}\mathrm{CO}_{2} \text { emissions } \\
\text { In } 1990 \\
\left(\mathrm{Mt} \mathrm{CO}_{2}\right)\end{array}$ & $\begin{array}{c}\mathrm{CO}_{2} \text { emissions } \\
\text { In } 2000 \\
\left(\mathrm{Mt} \mathrm{CO}_{2}\right)\end{array}$ & $\begin{array}{c}\mathrm{CO}_{2} \text { emissions } \\
\text { In } 2005 \\
\left(\mathrm{Mt} \mathrm{CO}_{2}\right)\end{array}$ & $\begin{array}{c}\mathrm{CO}_{2} \text { emissions } \\
\text { In } 2020 \\
\left.(\mathrm{Mt} \mathrm{CO})_{2}\right)\end{array}$ & $\begin{array}{l}\text { Reduction } \\
\text { requirements } \\
\text { in } 2020 \\
(\% \text { vs. } 1990)\end{array}$ & $\begin{array}{l}\text { Reduction } \\
\text { requirements } \\
\text { in } 2020 \\
(\% \text { vs. } 2000)\end{array}$ & $\begin{array}{l}\text { Reduction } \\
\text { requirements } \\
\text { in } 2020 \\
(\% \text { vs. } 2005)\end{array}$ & $\begin{array}{c}\text { Reduction } \\
\text { requirements } \\
\text { in } 2020 \\
\text { (\% vs. } 2020)\end{array}$ \\
\hline Austria & 59.6 & & & 74.1 & 24.3 & & & 39.1 \\
\hline Belgium & 110.1 & & & 143.9 & 19.6 & & & 38.5 \\
\hline Denmark & 50.4 & & & 59.1 & 31.3 & & & 41.4 \\
\hline Finland & 54.2 & & & 65.2 & 13.0 & & & 27.7 \\
\hline France & 377.3 & & & 421.0 & 13.0 & & & 22.1 \\
\hline Germany & 988.3 & & & 963.0 & 31.3 & & & 29.5 \\
\hline Greece & 75.8 & & & 106.1 & -8.7 & & & 22.3 \\
\hline Ireland & 33.0 & & & 49.8 & 1.7 & & & 34.9 \\
\hline Italy & 417.5 & & & 511.7 & 18.7 & & & 33.7 \\
\hline Netherlands & 158.5 & & & 201.8 & 18.3 & & & 35.8 \\
\hline Portugal & 43.6 & & & 74.7 & -10.4 & & & 35.6 \\
\hline Spain & 225.8 & & & 351.1 & 0.0 & & & 35.7 \\
\hline Sweden & 49.8 & & & 49.8 & 9.6 & & & 9.6 \\
\hline United Kingdom & 577.4 & & & 646.5 & 23.9 & & & 32.0 \\
\hline Eastern Europe & 1042.1 & & & 1110.4 & 8.8 & & & 14.4 \\
\hline EU-27 & 4263.4 & & & 4828.1 & 20.0 & & & 27.2 \\
\hline Canada & 427.5 & 521.8 & 578.5 & 602.3 & -8.3 & & 20.0 & 23.2 \\
\hline Japan & 1091.4 & 1225.6 & 1271.1 & 1168.3 & -0.2 & & 14.0 & 6.4 \\
\hline Former Soviet Union & 3605.4 & 2311.4 & 2401.0 & 2764.3 & 23.3 & & & 0.0 \\
\hline Pacific OECD & 292.0 & 369.2 & 420.4 & 446.1 & -13.8 & 10.0 & & 25.5 \\
\hline United States & 4890.8 & 5766.2 & 6237.5 & 6500.0 & 0.0 & & & 24.8 \\
\hline Brazil & 214.0 & & & 838.2 & - & & & - \\
\hline China & 2495.7 & & & 6491.2 & - & & & - \\
\hline India & 616.1 & & & 2934.5 & - & & & - \\
\hline Mexico & 309.0 & & & 733.7 & - & & & - \\
\hline South Korea & 253.7 & & & 853.0 & - & & & - \\
\hline
\end{tabular}




\section{Appendix B Core simulation results}

Table 6 Total compliance costs by region and scenario (million €2005)

\begin{tabular}{|c|c|c|c|c|c|c|c|c|c|c|c|c|}
\hline Region & IET & CDM & REDD & $\begin{array}{c}\text { REDD_ } \\
\text { SUP }\end{array}$ & $\begin{array}{c}\text { REDD_- } \\
\text { DEM }\end{array}$ & $\begin{array}{l}\text { REDD_ } \\
\text { MAC }\end{array}$ & $\begin{array}{c}\text { REDD_ } \\
\text { MAC }\end{array}$ & $\begin{array}{l}\text { REDD } \\
\text { EXP }\end{array}$ & $\begin{array}{c}\text { REDD_ } \\
\text { SUP } \\
\text { EXP } \\
\end{array}$ & $\begin{array}{c}\text { REDD_ } \\
\text { DEM } \\
\text { EXP } \\
\end{array}$ & $\begin{array}{c}\text { REDD_ } \\
\text { MAC } \\
\text { EXP } \\
\end{array}$ & $\begin{array}{c}\mathrm{REDD}_{-} \\
\mathrm{MAC}+ \\
\mathrm{EXP}\end{array}$ \\
\hline EU-27 & 34708.6 & 17874.3 & 10415.2 & 14667.4 & 12380.5 & 8300.4 & 12476.4 & 30633.1 & 22007.7 & 18927.3 & 25018.7 & 35338.9 \\
\hline Canada & 2630.4 & 1659.1 & 1027.2 & 1398.8 & 1157.7 & 831.8 & 1211 & 3013.9 & 2097.7 & 1770.9 & 2495.5 & 3437.5 \\
\hline Japan & 624.6 & 724.9 & 495.6 & 640.6 & 512.2 & 410.7 & 570.3 & 1452.3 & 960.2 & 784.8 & 1227.5 & 1626.1 \\
\hline $\begin{array}{l}\text { Former Sov. } \\
\text { Un. } \\
\end{array}$ & -14198 & -3308.6 & -1173.6 & -2248.4 & -2228.6 & -768.3 & -1650 & -3297.4 & -3308.5 & -3308.6 & -2273.5 & -4298.3 \\
\hline Pacific OECD & 2067.1 & 1499.6 & 898.1 & 1250.5 & 1052.5 & 717.9 & 1071.1 & 2606.2 & 1858 & 1590.7 & 2147.5 & 2973.5 \\
\hline United States & 28428.5 & 19195.1 & 11977.6 & 16264 & 13479.4 & 9697.1 & 14108.4 & 34843.3 & 24261.3 & 20486.2 & 28927.9 & 39622.6 \\
\hline \begin{tabular}{|l} 
Annex I \\
regions
\end{tabular} & 54261.2 & 37644.4 & 23640.1 & 31972.9 & 26353.7 & 19189.6 & 27787.2 & 69251.4 & 47876.4 & 40251.3 & 57543.6 & 78700.3 \\
\hline Brazil & & -40.1 & -11.7 & -25.3 & -25.1 & -7.1 & -17.6 & -40 & -40.1 & -40.1 & -25.6 & -54.9 \\
\hline China & & -11353 & -3231.1 & -7116.9 & -7040.3 & -1939.4 & -4885.4 & -11307.8 & -11353 & -11353 & -7214.5 & -15513.4 \\
\hline South Korea & & -412.4 & -119.9 & -259.8 & -257 & -72.8 & -179.6 & -410.8 & -412.4 & -412.4 & -263.3 & -564.2 \\
\hline Mexico & & -495.2 & -184.9 & -342.3 & -339.4 & -124.1 & -255.1 & -493.6 & -495.2 & -495.2 & -346 & -636.8 \\
\hline India & & -1496.8 & -416 & -921.4 & -911.2 & -250.5 & -629.2 & -1490.4 & -1496.8 & -1496.8 & -934.3 & -2093.5 \\
\hline CDM regions & & -13797.5 & -3963.6 & -8665.7 & -8573 & -2393.9 & -5966.9 & -13742.6 & -13797.5 & -13797.5 & -8783.7 & -18862.8 \\
\hline Africa & & & -5136.8 & -2917 & -718.7 & -2505.2 & -6124.7 & -14113.1 & -3790.7 & -718.7 & -8805.8 & -16213.2 \\
\hline South-East Asia & & & -180.4 & -389.8 & -38.9 & -13.8 & -193.9 & -617.6 & -617.3 & -38.9 & -58.3 & -610.6 \\
\hline Central America & & & -162.7 & -276.9 & -35.1 & -24.9 & -171.3 & -556.8 & -374.7 & -35.1 & -95.1 & -539.1 \\
\hline South America & & & -1323.8 & -2394.6 & -285.5 & -202.9 & -1393.7 & -4530 & -3275.1 & -285.5 & -773.7 & -4386.1 \\
\hline REDD regions & & & -6803.7 & -5978.3 & -1078.2 & -2746.8 & -7883.6 & -19817.5 & -8057.8 & -1078.2 & -9732.9 & -21749 \\
\hline
\end{tabular}


Table 7 Emission reductions by region and scenario (\% of BaU emissions)

\begin{tabular}{|c|c|c|c|c|c|c|c|c|}
\hline Region & IET & $\mathrm{CDM}$ & REDD & $\begin{array}{c}\text { REDD_SU } \\
\mathrm{P}\end{array}$ & $\begin{array}{c}\text { REDD_DE } \\
\mathrm{M}\end{array}$ & $\begin{array}{l}\text { REDD } \\
\text { EXP }\end{array}$ & $\begin{array}{c}\text { REDD_SU } \\
\text { P } \\
\text { EXP }\end{array}$ & $\begin{array}{c}\text { REDD_DE } \\
\text { M } \\
\text { EXP }\end{array}$ \\
\hline EU-27 & 15.2 & 7.2 & 4 & 5.8 & 5.8 & 7.2 & 7.2 & 7.2 \\
\hline Canada & 20.4 & 10.6 & 6.3 & 8.8 & 8.7 & 10.6 & 10.6 & 10.6 \\
\hline Japan & 8.8 & 4.5 & 2.7 & 3.8 & 3.7 & 4.5 & 4.5 & 4.5 \\
\hline $\begin{array}{l}\text { Former Sov. } \\
\text { Un. }\end{array}$ & 22.1 & 12.8 & 8.6 & 11 & 11 & 12.8 & 12.8 & 12.8 \\
\hline Pacific OECD & 27.9 & 9.5 & 4.3 & 6.9 & 6.9 & 9.5 & 9.5 & 9.5 \\
\hline United States & 23.9 & 11.9 & 6.6 & 9.6 & 9.5 & 11.8 & 11.9 & 11.9 \\
\hline Brazil & 0 & 0.5 & 0.3 & 0.4 & 0.4 & 0.5 & 0.5 & 0.5 \\
\hline China & 0 & 20.6 & 10.7 & 16.3 & 16.2 & 20.6 & 20.6 & 20.6 \\
\hline South Korea & 0 & 5.7 & 3 & 4.5 & 4.5 & 5.7 & 5.7 & 5.7 \\
\hline Mexico & 0 & 6.4 & 4.3 & 5.5 & 5.5 & 6.4 & 6.4 & 6.4 \\
\hline India & 0 & 6.1 & 3 & 4.6 & 4.6 & 6.1 & 6.1 & 6.1 \\
\hline Africa & 0 & 0 & 77.9 & 19.3 & 34.3 & 94.9 & 19.3 & 34.3 \\
\hline South-East Asia & 0 & 0 & 10.7 & 15.8 & 4.9 & 20 & 19.3 & 4.9 \\
\hline Central America & 0 & 0 & 22.5 & 19.3 & 10.3 & 42.2 & 19.3 & 10.3 \\
\hline South America & 0 & 0 & 20.4 & 19.3 & 9.3 & 38.2 & 19.3 & 9.3 \\
\hline
\end{tabular}


Table 8 Carbon prices by credit type and scenario ( $€ 2005$ per ton of $\mathrm{CO}_{2}$ )

\begin{tabular}{|c|c|c|c|c|c|c|c|c|c|c|c|c|}
\hline Type Scenario & IET & CDM & REDD & $\begin{array}{c}\text { REDD_ } \\
\text { SUP }\end{array}$ & $\begin{array}{c}\text { REDD_- } \\
\text { DEM }\end{array}$ & $\begin{array}{c}\text { REDD_- } \\
\text { MAC }\end{array}$ & $\begin{array}{c}\text { REDD_- } \\
\mathrm{MAC}+\end{array}$ & $\begin{array}{l}\text { REDD } \\
\text { EXP }\end{array}$ & $\begin{array}{l}\text { REDD_ } \\
\text { SUP } \\
\text { EXP }\end{array}$ & $\begin{array}{c}\text { REDD_- } \\
\text { DEM } \\
\text { EXP }\end{array}$ & $\begin{array}{c}\text { REDD_- } \\
\text { MAC } \\
\text { EXP }\end{array}$ & $\begin{array}{c}\mathrm{REDD}_{-} \\
\mathrm{MAC}+ \\
\mathrm{EXP}\end{array}$ \\
\hline $\begin{array}{l}\text { International } \\
\text { permit price }\end{array}$ & 37.9 & 15.7 & 8.6 & 12.5 & 12.5 & 6.7 & 10.4 & 15.7 & 15.7 & 15.7 & 12.6 & 18.4 \\
\hline CDM price & 0 & 15.7 & 8.6 & 12.5 & 12.5 & 6.7 & 10.4 & 15.7 & 15.7 & 15.7 & 12.6 & 18.4 \\
\hline REDD price & 0 & 0 & 8.6 & 12.5 & 4 & 6.7 & 10.4 & 15.7 & 15.7 & 4 & 12.6 & 18.4 \\
\hline
\end{tabular}

Table 9 Market volumes of CDM and REDD credits $\left(\mathrm{Mt} \mathrm{CO}_{2}\right)$

\begin{tabular}{|c|c|c|c|c|c|c|c|c|c|c|c|c|}
\hline Market & IET & $\mathrm{CDM}$ & REDD & $\begin{array}{l}\text { REDD_ } \\
\text { SUP }\end{array}$ & $\begin{array}{c}\text { REDD_ } \\
\text { DEM }\end{array}$ & $\begin{array}{c}\text { REDD_ } \\
\text { MAC }\end{array}$ & $\begin{array}{l}\mathrm{REDD}_{-} \\
\mathrm{MAC}+\end{array}$ & $\begin{array}{l}\text { REDD } \\
\text { EXP }\end{array}$ & $\begin{array}{l}\text { REDD_- } \\
\text { SUP } \\
\text { EXP }\end{array}$ & $\begin{array}{c}\text { REDD_- } \\
\text { DEM } \\
\text { EXP }\end{array}$ & $\begin{array}{c}\text { REDD_ } \\
\text { MAC } \\
\text { EXP }\end{array}$ & $\begin{array}{l}\text { REDD_- } \\
\text { MAC+ } \\
\text { EXP }\end{array}$ \\
\hline $\begin{array}{l}\text { REDD market } \\
\text { volume }\end{array}$ & 0 & 0 & 1462.9 & 636.3 & 650.1 & 1857 & 1066 & 2021.2 & 650 & 649.7 & 2635 & 1519 \\
\hline
\end{tabular}


Table 10 Net CDM credit exports (exports less imports, $\mathrm{Mt} \mathrm{CO}_{2}$ )

\begin{tabular}{|c|c|c|c|c|c|c|c|c|}
\hline Region & IET & CDM & REDD & $\begin{array}{c}\text { REDD_SU } \\
\text { P }\end{array}$ & $\begin{array}{c}\text { REDD_DE } \\
\mathrm{M}\end{array}$ & $\begin{array}{c}\text { REDD } \\
\text { EXP }\end{array}$ & $\begin{array}{c}\text { REDD_SU } \\
\text { P } \\
\text { EXP }\end{array}$ & $\begin{array}{c}\text { REDD_DE } \\
\text { M } \\
\text { EXP }\end{array}$ \\
\hline Brazil & 0 & 4.5 & 2.3 & 3.6 & 3.6 & 4.5 & 4.5 & 4.5 \\
\hline China & 0 & 1338.3 & 693 & 1059.3 & 1053.4 & 1335.8 & 1338.3 & 1338.3 \\
\hline South Korea & 0 & 48.9 & 25.5 & 38.5 & 38.3 & 48.8 & 48.9 & 48.9 \\
\hline Mexico & 0 & 47 & 31.8 & 40.7 & 40.5 & 47 & 47 & 47 \\
\hline India & 0 & 179.1 & 87.2 & 136.1 & 135.2 & 178.7 & 179.1 & 179.1 \\
\hline $\begin{array}{l}\text { Annex I } \\
\text { regions }\end{array}$ & 0 & -1618.3 & -839.8 & -1277.9 & -1271 & -1615 & -1618.1 & -1617.8 \\
\hline
\end{tabular}

Table 11 Net REDD credit exports (exports less imports, $\mathrm{Mt} \mathrm{CO}_{2}$ )

\begin{tabular}{|c|c|c|c|c|c|c|c|c|c|c|c|c|}
\hline Region & IET & CDM & REDD & $\begin{array}{c}\text { REDD_ } \\
\text { SUP }\end{array}$ & $\begin{array}{c}\text { REDD_ } \\
\text { DEM }\end{array}$ & $\begin{array}{l}\text { REDD_ } \\
\text { MAC }\end{array}$ & $\begin{array}{l}\text { REDD_- } \\
\text { MAC+ }\end{array}$ & $\begin{array}{l}\text { REDD } \\
\text { EXP }\end{array}$ & $\begin{array}{c}\text { REDD_ } \\
\text { SUP } \\
\text { EXP }\end{array}$ & $\begin{array}{c}\text { REDD_ } \\
\text { DEM } \\
\text { EXP }\end{array}$ & $\begin{array}{c}\text { REDD_ } \\
\text { MAC } \\
\text { EXP }\end{array}$ & $\begin{array}{c}\text { REDD_ } \\
\text { MAC+ } \\
\text { EXP }\end{array}$ \\
\hline Africa & 0 & 0 & 1097.5 & 271.9 & 482.6 & 1275.9 & 847 & 1336.9 & 271.9 & 482.6 & 1526.6 & 1126.5 \\
\hline South-East Asia & 0 & 0 & 40.7 & 60.3 & 18.6 & 64.8 & 24.4 & 76.2 & 73.6 & 18.6 & 123.3 & 43.8 \\
\hline Central America & 0 & 0 & 35.5 & 30.4 & 16.3 & 56.6 & 21.3 & 66.6 & 30.4 & 16.3 & 107.8 & 38.2 \\
\hline South America & 0 & 0 & 289 & 274 & 132.5 & 460.3 & 173.6 & 541.5 & 274 & 132.5 & 877.2 & 310.8 \\
\hline \begin{tabular}{|l} 
Annex I \\
regions
\end{tabular} & 0 & $\mathbf{0}$ & -1462.9 & -636.3 & -650.1 & -1857.6 & 1066.3 & -2021.2 & -650 & -649.7 & -2634.9 & -1519.3 \\
\hline
\end{tabular}


Table 12 Core and expanded Annex I emission reduction commitments by region and scenario (commitments in \% vs. BAU emissions in 2020)

\begin{tabular}{|l|r|r|r|r|}
\hline Region & CDM & \multicolumn{1}{|c|}{$\begin{array}{l}\text { REDD } \\
\text { EXP }\end{array}$} & $\begin{array}{c}\text { REDD_SUP } \\
\text { EXP }\end{array}$ & $\begin{array}{l}\text { REDD_DEM } \\
\text { EXP }\end{array}$ \\
\hline EU-27 & 27.2 & 44.1 & 32.6 & 32.6 \\
\hline Canada & 23.2 & 37.6 & 27.8 & 27.8 \\
\hline Japan & 6.4 & 10.4 & 7.7 & 7.7 \\
\hline Former Sov. Un. & 0.0 & 0.0 & 0.0 & 0.0 \\
\hline Pacific OECD & 25.5 & 41.4 & 30.6 & 30.6 \\
\hline United States & 24.8 & 40.1 & 29.7 & 29.7 \\
\hline Annex I regions & $\mathbf{1 9 . 9}$ & $\mathbf{3 2 . 3}$ & $\mathbf{2 3 . 9}$ & $\mathbf{2 3 . 9}$ \\
\hline $\begin{array}{l}\text { Relative } \\
\text { expansion of } \\
\text { commitment }\end{array}$ & $0 \%$ & $62 \%$ & $20 \%$ & $20 \%$ \\
\hline
\end{tabular}

\section{Appendix C Simulations results for sensitivity analysis}

Table 13 Carbon prices by credit type and scenario ( $€ 2005$ per ton of $\mathrm{CO}_{2}$ )

\begin{tabular}{|c|c|c|c|c|c|c|c|}
\hline Scenario & $\begin{array}{l}\text { BASE } \\
\text { CASE }\end{array}$ & REDD & $\begin{array}{l}\text { REDD_ } \\
\text { MAC }\end{array}$ & $\begin{array}{l}\text { REDD_- } \\
\text { MAC+ }\end{array}$ & $\begin{array}{l}\text { REDD } \\
\text { EXP }\end{array}$ & $\begin{array}{c}\text { REDD_ } \\
\text { MAC } \\
\text { EXP } \\
\end{array}$ & $\begin{array}{c}\text { REDD_ } \\
\text { MAC+ } \\
\text { EXP } \\
\end{array}$ \\
\hline $\begin{array}{l}\text { International permit } \\
\text { price }\end{array}$ & 15.7 & 8.6 & 6.7 & 10.4 & 15.7 & 12.6 & 18.4 \\
\hline CDM price & 15.7 & 8.6 & 6.7 & 10.4 & 15.7 & 12.6 & 18.4 \\
\hline REDD price & & 8.6 & 6.7 & 10.4 & 15.7 & 12.6 & 18.4 \\
\hline
\end{tabular}


Table 14 Total compliance costs and economic benefits by region and scenario (million €2005)

\begin{tabular}{|c|c|c|c|c|c|c|c|}
\hline Scenario & $\begin{array}{l}\text { BASE } \\
\text { CASE }\end{array}$ & REDD & $\begin{array}{c}\text { REDD_ } \\
\text { MAC }\end{array}$ & $\begin{array}{c}\text { REDD_- } \\
\text { MAC+ }\end{array}$ & $\begin{array}{l}\text { REDD } \\
\text { EXP }\end{array}$ & $\begin{array}{c}\text { REDD_- } \\
\text { MAC } \\
\text { EXP }\end{array}$ & $\begin{array}{c}\text { REDD_ } \\
\text { MAC+ } \\
\text { EXP }\end{array}$ \\
\hline EU-27 & 17874.3 & 10415.2 & 8300.4 & 12476 & 30633.1 & 25018.7 & 35338.9 \\
\hline Canada & 1659.1 & 1027.2 & 831.8 & 1211 & 3013.9 & 2495.5 & 3437.5 \\
\hline Japan & 724.9 & 495.6 & 410.7 & 570 & 1452.3 & 1227.5 & 1626.1 \\
\hline Former Soviet Union & -3308.6 & -1173.6 & -768.3 & -1650 & -3297.4 & -2273.5 & -4298.3 \\
\hline Pacific OECD & 1499.6 & 898.1 & 717.9 & 1071 & 2606.2 & 2147.5 & 2973.5 \\
\hline United States & 19195.1 & 11977.6 & 9697.1 & 14108 & 34843.3 & 28927.9 & 39622.6 \\
\hline Annex I regions & 37644.4 & 23640.1 & 19189.6 & 27787 & 69251.4 & 57543.6 & 78700.3 \\
\hline Brazil & -40.1 & -11.7 & -7.1 & -17.6 & -40 & -25.6 & -54.9 \\
\hline China & -11353 & -3231.1 & -1939.4 & -4885 & -11307.8 & -7214.5 & -15513.4 \\
\hline South Korea & -412.4 & -119.9 & -72.8 & -180 & -410.8 & -263.3 & -564.2 \\
\hline Mexico & -495.2 & -184.9 & -124.1 & -255 & -493.6 & -346 & -636.8 \\
\hline India & -1496.8 & -416 & -250.5 & -629 & -1490.4 & -934.3 & -2093.5 \\
\hline CDM regions & -13798 & -3963.6 & -2393.9 & -5967 & -13742.6 & -8783.7 & -18862.8 \\
\hline Africa & & -5136.8 & -2505.2 & -6124 & -14113.1 & -8805.8 & \begin{tabular}{|l|}
-16213.2 \\
\end{tabular} \\
\hline South-East Asia & & -180.4 & -13.8 & -194 & -617.6 & -58.3 & -610.6 \\
\hline Central America & & -162.7 & -24.9 & -171 & -556.8 & -95.1 & -539.1 \\
\hline South America & & -1323.8 & -202.9 & -1394 & -4530 & -773.7 & -4386.1 \\
\hline REDD regions & & -6803.7 & -2746.8 & -7884 & -19817.5 & -9732.9 & -21749 \\
\hline
\end{tabular}

Note: Negative compliance costs represent net economic benefits

Table 15 Market volumes of CDM and REDD credits $\left(\mathrm{Mt} \mathrm{CO}_{2}\right)$

\begin{tabular}{|l|r|r|r|r|r|r|r|}
\hline Region Scenario & $\begin{array}{l}\text { BASE } \\
\text { CASE }\end{array}$ & REDD & $\begin{array}{r}\text { REDD_ } \\
\text { MAC }\end{array}$ & $\begin{array}{c}\text { REDD_ } \\
\text { MAC+ }\end{array}$ & $\begin{array}{r}\text { REDD } \\
\text { EXP }\end{array}$ & $\begin{array}{c}\text { REDD_ } \\
\text { MAC } \\
\text { EXP }\end{array}$ & $\begin{array}{c}\text { REDD_- } \\
\text { MAC+ } \\
\text { EXP }\end{array}$ \\
\hline CDM market volume & 1618 & 840 & 635 & 1048 & 1618 & 1287 & 1880 \\
\hline REDD market volume & & 1463 & 1857 & 1066 & 2021.2 & 2635 & 1519 \\
\hline
\end{tabular}

